\title{
Green Strategic Planning Approach for International Shipping Activities
}

\author{
Xiaofang $\mathrm{Wu}^{1}$, Luoping Zhang ${ }^{2, *}{ }^{\mathbb{D}}$ and Huan Feng ${ }^{3}(\mathbb{C}$ \\ 1 College of Harbour and Environmental Engineering, Jimei University, Xiamen 361021, China; \\ xiaofang.wu@jmu.edu.cn \\ 2 Coastal and Ocean Management Institute, Xiamen University, Xiamen 361102, China \\ 3 Department of Earth and Environmental Studies, Montclair State University, Montclair, NJ 07043, USA; \\ fengh@montclair.edu \\ * Correspondence: lpzhang@xmu.edu.cn
}

Received: 15 November 2019; Accepted: 17 December 2019; Published: 19 December 2019

\begin{abstract}
Sustainability is a long-term and ultimate goal for international shipping, although it is slowly making progress. The shipping perspective that moves away from "port-to-port" operations to "door-to-door" services also requires international shipping to take a long-term and holistic view instead of fragmented efforts. How to achieve the long-term sustainability goal becomes a key issue for door-to-door international shipping. Hence, green strategic planning for door-to-door international shipping was proposed with green development that puts forward the eco-centric point of view as its basic theory for sustainability. This study used a strategic decision-making approach, a so-called multi-dimensional decision-making (MDDM), coupled with the life-cycle thinking and continual improvement of ISO 14000, to achieve strategic planning for door-to-door international shipping aiming at sustainability. A case study showed an example of potential framework and/or methodology for the door-to-door international shipping, which integrates green development principles into international shipping planning to reach the long-term goal of sustainability, and meet the needs of the "door-to-door" logistics. It not only points out the general environmental problems but also identifies many critical issues for sustainability in international shipping. As a result, this study developed an approach and methods for sustainable door-to-door international shipping based on the proactively strategic decision-making associated with green development.
\end{abstract}

Keywords: international shipping; strategic planning; green development; sustainability

\section{Introduction}

Sustainability has been viewed as a long-term and ultimate goal of human beings [1], and green development and sustainable development have been the two prominent approaches to sustainability [2]. The most commonly used sustainable development serves a human being's needs through human governance [3]. However, this anthropocentric attitude ignores the essence of sustainability [4] and, hence, has been considered to be the root of environmental and ecological crises [5,6]. Sustainability considers eco-centrism to be its key pathway [7] and commits to the conservation of natural resources [4] because the natural ecosystem is fundamental to human existence [8]. In the meantime, green development has been theoretically based on non-anthropocentrism or eco-centrism and has been targeting nature conservation [2]. This point of view, which puts human beings as part of nature, has been proven to be a key to sustainability $[7,9]$. To achieve the sustainability goal and avoid the depletion of natural resources, we must place nature first [10], and work on the principles of "nature-center" and "maintenance of natural intrinsic value" following the green development approach [2]. 
Communities around the world have recently made more commitments to sustainable development and are becoming more concerned about climate change following the ongoing implementation of United Nations 2030 Agenda's Sustainable Development Goals (SDGs) and the Paris Agreement [11-13]. Accordingly, the International Maritime Organization (IMO), which is a global regulation-setting organization for international shipping, integrated the SDGs into its organization's strategic goals for 2018-2023 [14], and then requested at least $40 \%$ reduction in $\mathrm{CO}_{2}$ emissions by 2030 from the 2008 baseline [15] and $0.50 \%$ mass limit of sulfur content in marine fuels starting from 2020 [16]. However, $\mathrm{CO}_{2}$ emission from international freight at sea is expected to be increased by $163 \%$ in 2050 comparing to that in 2015 [17]. IMO has very limited authority to force the implementation of the SDGs [18]. With sustainable development, the current sustainable shipping practices are also facing challenges in achieving sustainability due to human preferences $[2,19]$.

Additionally, international shipping in the age of globalization has already expanded its operation mode from "port-to-port" marine transportation to "door-to-door" multi-modal transportation by deploying larger ships and applying advanced technologies $[20,21]$. The shipping services can certainly improve efficiency and reduce costs from a seamless door-to-door intermodal transportation perspective [22]. However, most of the sustainability studies in international shipping, including those from IMO and national governments or the framework of the United Nations Conference on Trade and Development (UNCTAD) for sustainable freight transport, still consider international shipping from the perspective of port-to-port [23,24]. The fragmented management cannot satisfy the door-to-door transition challenge and meet the sustainability requirement with a long-term and ultimate goal in international shipping [24-26].

While moving towards the long-term and ultimate goal of sustainability, a systematic and constructed process to formulate strategies, namely strategic planning, is needed $[25,27,28]$. This indispensable tool can facilitate decision-making, execute strategies for shipping, and achieve this goal [29] in such a complex environment [30]. Current strategic planning for international shipping heavily relies on either data-driven or vision-/goal-oriented approaches and there is a lack of appropriate approaches and methods for cross-regional and multi-jurisdictional door-to-door international shipping [24]. All these make it very difficult for IMO and leading multimodal shipping companies to share the information and work collaboratively.

Thus, the purpose of this study is to develop an appropriate approach and methods for the door-to-door international shipping strategic planning towards sustainability. This is beyond an organization's authority and proactively brings trans-disciplinary knowledge to share and collaborate. In this paper, a conceptual model and method analysis are given, followed by discussion and a case study.

\section{Materials and Methods}

\subsection{Methods}

This study started with proposing a concept for green strategic planning for international shipping based on the review of relevant concepts on international shipping, green development, green shipping, a long-term goal of sustainability, strategic decision-making, and door-to-door services. Then, a green strategic planning approach was developed for international shipping activities according to the requirements of the proposed concept. Recommendations for a series of methods were also given to enable the planning process. Finally, we performed a case study to discuss and examine the proposed approach and methodology.

The assessment in the case study was conducted by authors using the methods described in Section 3.3.3, based on the data collected. The detailed assessment results are shown in Supplementary Materials I and II. The experts, who understood the international shipping activities and were familiar with the regional environments, were invited and consulted to score all impact $(I)$, confidence $(C)$ and relationship $(R)$ for the decision-making. 


\subsection{Materials}

In this study, all the data related to all shipping operations in the door-to-door life-cycle and the six dimensions in all areas of the life-cycle of logistics, including passing and transition areas, were collected from interviews, surveys, literature search, statistical yearbooks, annual reports, official documents, and online access to official websites of governments and other relevant organizations (as shown in Table A1 in the Appendix A).

\section{Results}

\subsection{Concept of Green Strategic Planning for International Shipping}

International shipping is defined as the entire worldwide shipping process with marine transportation being involved $[21,31]$. This concept sets the shipping function, i.e., the conveyance of cargo from one place to another [32,33], into an international scope and serves more than $80 \%$ of world trade in terms of volume [34].

To acknowledge the concept of green development as a sustainability approach, green shipping has been proposed, which is based on the concept of green development rather than sustainable development in theory [2]. Furthermore, the concept of green shipping as defined by Wu et al. [2] provides a theoretical basis and objectives for green strategic planning in international shipping, which integrates a long-term goal, strategic decision-making, green development, and door-to-door services in order to actually achieve sustainability. Accordingly, door-to-door international shipping can be defined as an effort to generate strategies for door-to-door worldwide movements in accordance with the sustainability requirements, as below:

- Emphasize the point of view of nature first and the green development approach rather than the satisfaction of human needs and aspirations [34], and acknowledge the intrinsic value of the natural ecosystem [7,35] to conserve natural resources and biodiversity [36,37];

- Make systematic strategic decisions for the green strategic planning of international shipping, instead of fragmented efforts [26], towards the long-term sustainability goals; and

- Get the whole door-to-door international shipping process involved, i.e., shipping logistics supply from supply place to receipt place with ocean carriage being involved [21,31], rather than port-to-port shipping, to ensure sustainability throughout the whole process.

This definition is based on non-anthropocentrism and eco-centrism, considers human beings as part of nature, and aims at green development to real sustainability through the maintenance of a natural ecosystem's intrinsic value. This definition satisfies the challenge of the door-to-door shipping transition and the sustainability requirement with a long-term and ultimate goal in international shipping [24-26].

\subsection{Greening Strategic Planning Approach for International Shipping}

\subsubsection{Principles}

The principles of green strategic planning for international shipping are set up based on the following proposed concepts:

- Value-focused thinking: This thinking is the decision-making basis [38]. Conservation cares about the natural intrinsic value [39];

- Resource-oriented principle: A resource is fundamental and essential to the sustainable development of concerns $[40,41]$. It helps define the objectives of regional development according to the characteristics of local resources [42];

- Strategic decision: Strategic planning is a systematic and long-term oriented process to formulate strategies [25]. Green shipping must use a strategic decision approach because sustainability is a 
long-term goal for human beings. The top-down strategic focus is a key component of strategic planning. It can be completed by combining with bottom-up information [43];

- Precautionary principle: This principle works through taking actions or measures even without enough understanding [44], which is critically important for international shipping, facing high uncertainties and complex global conditions;

- Life-cycle assessment [45]: It is a necessity to consider the life-cycle of international shipping because of the seamless operations, and due to this, green shipping planning is not for port-to-port operation, but door-to-door service;

- Continual improvement: This means "recurring activity to enhance performance" [46], which contributes to the dynamic strategic decision-making process for green development.

\subsubsection{Establishment}

As mentioned early, the current strategic planning approaches for international shipping are still limited to advising international shipping to meet the shipping transition and sustainability requirements [24]. A strategic decision-making approach, i.e., multi-dimensional decision-making (MDDM) approach, was applied to green strategic planning for door-to-door international shipping, which included: (1) identification of all relevant dimensions related to the goals or decision issues; (2) collection of all available data for all relevant dimensions; (3) retrospective assessment and current situation assessment; (4) generation of shipping alternatives; (5) integration of assessment in each dimension; and (6) decision-making [47]. This MDDM approach was proposed before for strategic decision-making processes and especially for regional and non-structured processes and has been effectively applied to several regional case studies in strategic decision-making [48,49].

Following the general MDDM logic framework and principles mentioned above, an approach for international shipping green strategic planning was developed in this study (Figure 1). This framework embraces planning dimension identification, door-to-door international shipping life-cycle determination, data collection and assessment, decision-making, green strategic planning, and continual improvements.

Specifically, the environmental dimensions in international shipping for sustainability include location, resource, society, economy, environment, and ecology, as recommended in previous case studies $[48,49]$. The location and resource dimensions express the statues of regional resources following the resource-oriented principle. The life-cycle of door-to-door international shipping involves all the operational activities occurring in the entire door-to-door process. The retrospective and current status assessment of six dimensions determined needs to be conducted to understand the status and trends of the regional environment, including the social and economic environment, with value-focused [50] and precautionary principles. If the preliminary assessment results are compliant with the mandatory laws, regulations, norms, and standards, then the planning can proceed to the next step. Otherwise, the planning ends. The next step is to assess each activity in the door-to-door international shipping life-cycle and the interaction between activities of the door-to-door shipping and regional environments from the aforementioned six dimensions perspectives. The strategic decision-making can be carried out using the MDDM model, consulting with expert judgment. If the decision shows good results, the green strategic planning and continual improvement can be drawn up to push international shipping to be greener and greener towards sustainability. If the decision results are not satisfactory, the process should go back to data collection, change decision-making alternative(s), environmental dimension(s), or shipping operation, and redraw the planning step-by-step. 


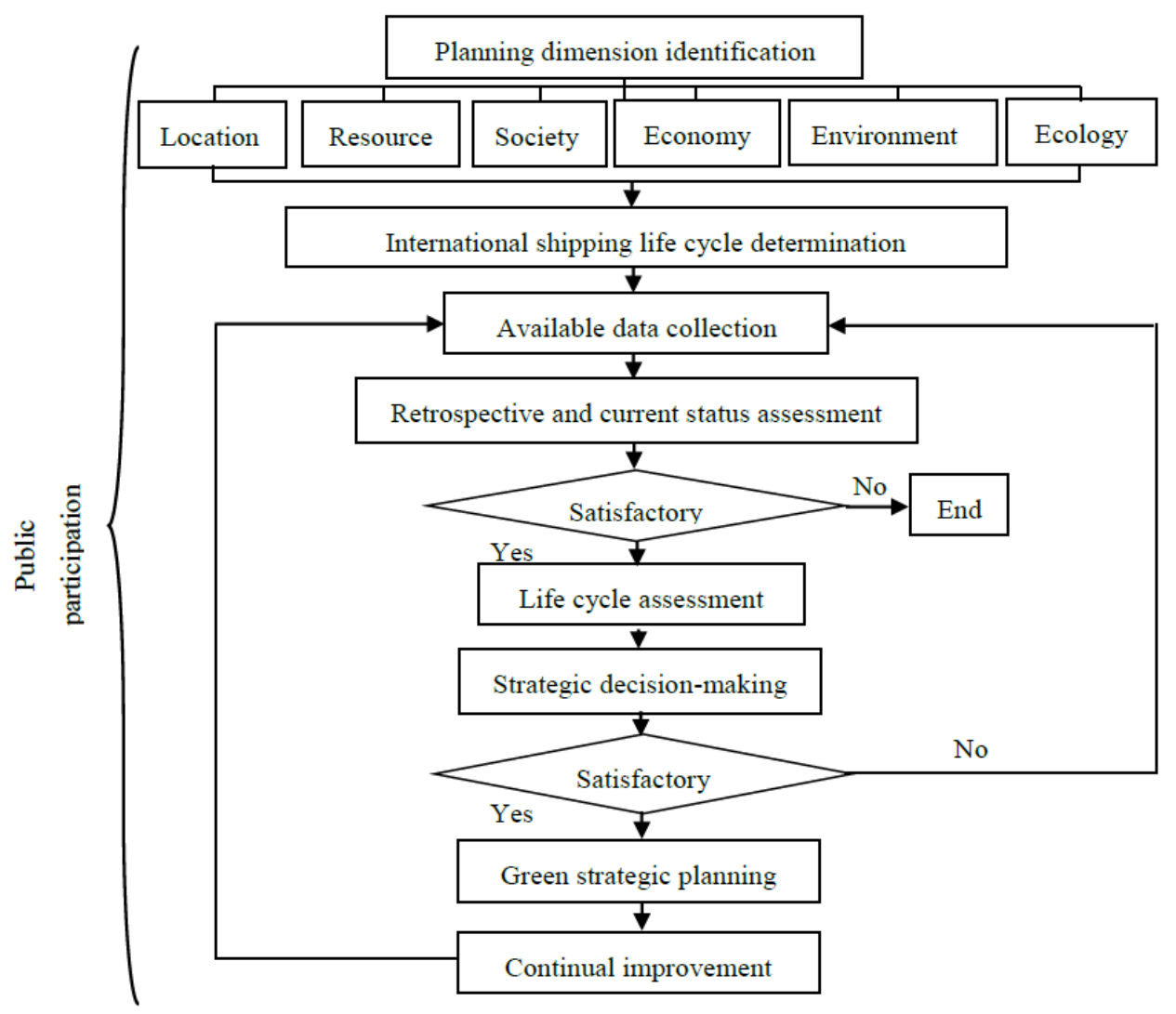

Figure 1. Green strategic planning approach for door-to-door international shipping.

This approach involves all related dimensions in the door-to-door shipping life-cycle and considers all available relevant parameters to ensure scientific feasibility and strategic decision-making reliability, applies the MDDM approach to the strategic decision-making process to overcome the inherent drawbacks of the multi-criteria decision-making (MCDM) approach [47] (see more discussion in Section 3.3.1), and makes green strategic planning and continual improvement for greener door-to-door international shipping towards sustainability.

\subsection{Recommended Methodology}

\subsubsection{Multi-Dimensional Decision-Making (MDDM)}

The MCDM approach, which includes the multiple-attributes and multiple-objectives decision-making approaches, has been widely used in business and sectoral public decision-making processes, but it is very difficult to apply to strategic decision-making processes, and especially to regional and non-structured strategic decision-making processes [47]. The MDDM approach was originally proposed to be used exclusively in strategic decision-making processes to address and overcome the inherent drawbacks in MCDM approaches, such as missing data, index selection, variable normalization, highly uncertainty and complexity, and weight assignment [47]. As a viable and effective tool for strategic planning against the background of a complex situation, MDDM can not only be used to frame the previous approach, but also to make a strategic decision by applying the MDDM model, $(I, C ; R)$, and expert judgments [47], where I represents impact, $C$ is confidence degree of the $I$ from expert judgments, and $R$ indicates the relationship between the dimensions of regional environment and the alternatives [47]. In this model, experts scores $(I, C$, and $R)$ are based on the assessment results and expert's experiences, where $I$ is $-3,-2,-1,0,1,2$, or $3, C$ is between 0 and 1 $(0,1]$, and $R$ is $0,1,2$, or 3 . The numbers $(0,1,2$, and 3$)$ imply no, small, medium, and strong impact 
or relationship, respectively. The negative sign suggests an adverse impact [47]. Then, interactions between the operational activities and the regional environments can be calculated by $[47,51]$ :

$$
\begin{aligned}
& S_{i}^{j}=\frac{\sum_{k=1}^{q} I_{k i}^{j} \times C_{k i}^{j} \times R_{k i}^{j}}{q}(k=1,2, \ldots, q ; i=1,2, \ldots, m ; j=1,2, \ldots, n) \\
& S_{j}^{i}=\frac{\sum_{k=1}^{q} I_{k j}^{i} \times C_{k j}^{i} \times R_{k j}^{i}}{q}(k=1,2, \ldots, q ; i=1,2, \ldots, m ; j=1,2, \ldots, n)
\end{aligned}
$$

where $i$ is the operational activity, $m$ is the total number of operational activities, $j$ is the dimension of regional environments, $n$ is the total number of environmental dimensions, $k$ indicates the expert's serial number, and $q$ is the total number of experts. $S_{i}^{j}$ describes the impacts of operational activity $i$ on the environmental dimension $j$, and $S_{j}^{i}$ represents the impacts of environmental dimension $j$ on the operational activity $i$.

\subsubsection{Life-Cycle Assessment (LCA) and "Continual Improvement" in ISO 14000}

ISO 14000, which was issued by the International Standardization Organization (ISO, 2015), includes a set of voluntary standards for environmental management and enables industries to improve their environmental performance to boost their competitiveness and reputation [52,53]. This international standard has been considered an effective guideline for shipping sustainability, especially the Life-cycle Assessment (LCA) and Environmental Management System (EMS) [54-56].

The LCA emphasizes life cycle thinking [45], which is consistent with the need for an "entire shipment process" of door-to-door international shipping. Life-cycle thinking can help to understand seamless shipping operations [21] and trans-boundary effects [57]. In this study, the life-cycle of a door-to-door logistics supply chain for international shipping could be described as all operational activities between the supplying and receiving areas. These activities include the production and storage of cargo in the supplying areas and the sale, consumption, disposal, and recycling of cargo in the receiving areas following the LCA concept (Figure 2). The current study focused only on general transport modes such as road transportation, rail transportation, inland waterway transportation, or marine transportation [58]. Moreover, possible LCA inventories and their indicators are summarized in Table 1.

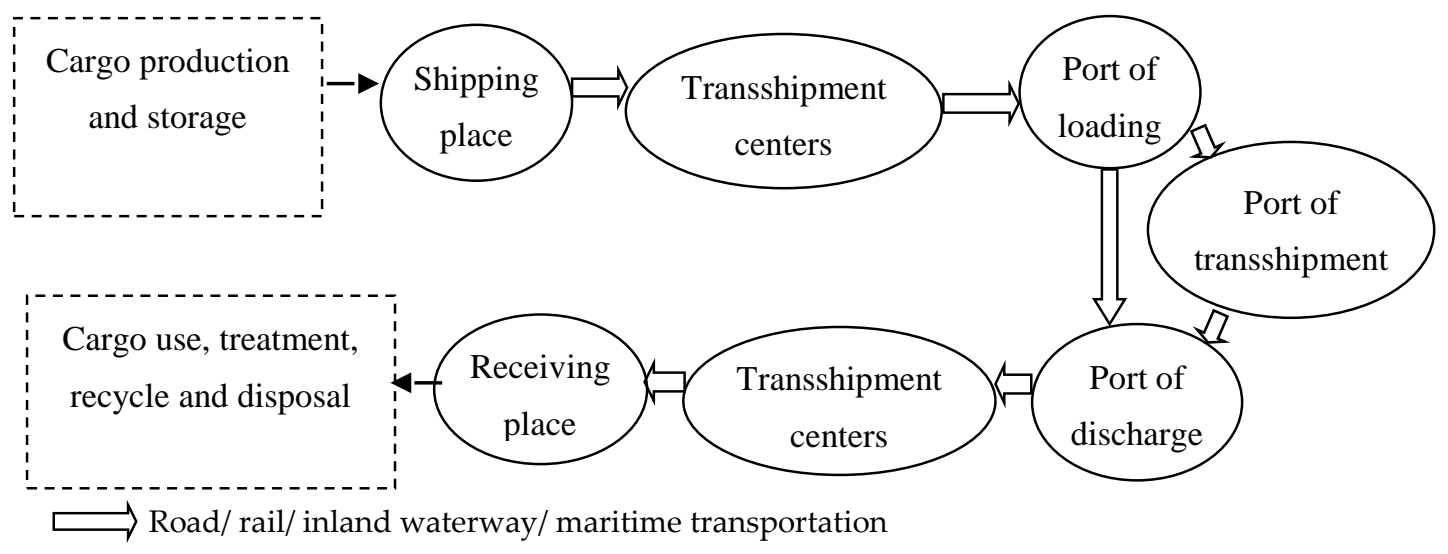

Figure 2. Life-cycle of a door-to-door logistics supply chain for international shipping. 
Table 1. International shipping life-cycle inventories and indicators in the door-to-door logistics supply chain.

\begin{tabular}{|c|c|c|}
\hline Processes & Activities & Contents for Assessment \\
\hline \multirow[t]{2}{*}{ Cargo production and storage } & Production & $\begin{array}{l}\text { Production processes, technologies, resource } \\
\text { consumption, energy efficiency, emissions, } \\
\text { and waste }\end{array}$ \\
\hline & Storage & $\begin{array}{l}\text { Storage methods, resource consumption, } \\
\text { emissions, and waste }\end{array}$ \\
\hline \multirow{2}{*}{$\begin{array}{l}\text { Transportation from land to sea or } \\
\text { from sea to land }\end{array}$} & Loading and discharge & $\begin{array}{l}\text { Type (e.g., automated), methods, resources } \\
\text { consumption, emissions, and waste }\end{array}$ \\
\hline & $\begin{array}{l}\text { Road transportation/rail } \\
\text { transportation/inland transportation }\end{array}$ & $\begin{array}{l}\text { Capacity, costs, benefits, fuel consumption, } \\
\text { energy efficiency, emissions, and waste }\end{array}$ \\
\hline Transshipment centers & $\begin{array}{l}\text { Loading and } \\
\text { discharge/packaging/distribution } \\
\text { processing/warehousing }\end{array}$ & $\begin{array}{l}\text { Type (e.g., automated), methods, resources } \\
\text { consumption, energy efficiency, emissions, } \\
\text { and waste }\end{array}$ \\
\hline \multirow[t]{3}{*}{ Operations in ports } & Loading/unloading/handling & $\begin{array}{l}\text { Type (e.g., automated), methods, resources } \\
\text { consumption, energy efficiency, emissions, } \\
\text { and waste }\end{array}$ \\
\hline & Storage & $\begin{array}{l}\text { Storage methods resource consumption, } \\
\text { emissions, and waste }\end{array}$ \\
\hline & Port traffic & $\begin{array}{l}\text { Traffic modes, resources consumption, energy } \\
\text { efficiency, emissions, and waste }\end{array}$ \\
\hline Port to port transportation & Maritime shipping & $\begin{array}{l}\text { Shipping routes, capacity (e.g., throughput), } \\
\text { costs, benefits, fuel consumption, energy } \\
\text { efficiency, emissions, and waste }\end{array}$ \\
\hline Storage in receiving place & Storage & $\begin{array}{l}\text { Storage methods, resources consumption, } \\
\text { emissions, and waste }\end{array}$ \\
\hline
\end{tabular}

Note: These potential indicators can be updated in response to specific requirements.

On the other hand, the EMS highlights continual improvement, suggesting that "recurring activity could enhance performance" [46]. This concept is good for the dynamic process of green strategic planning for international shipping, moving gradually towards sustainability.

\subsubsection{Assessment Methods}

In order to evaluate the multi-dimensional environment, some assessment methods were selected, and are listed below:

- Social assessment: Two techniques (i.e., public participation and expert judgment [48]) were chosen for social assessment to communicate with local people and share experts' experience using literature searches, questionnaires, interviews, and consultations;

- Economic assessment: Methods such as cost-effective analysis, benefit-cost analysis, and life-cycle cost analysis, are suggested to support the economic decision-making for international shipping [59]. The cost is effective when benefits exceed costs. The total incremental benefits are compared with total incremental costs in benefit-cost analysis;

- Environmental assessment: Environmental Impact Assessment (EIA) is a popular tool to take environmental issues into decision making process. It analyzes, predicts, and evaluates the possible environmental impacts of construction projects, and generates corresponding prevention and mitigation measures [60]. There is a set of EIA technical guidelines and standards developed by international organizations or each individual government [61]. The EIA also gives proper consideration from the social and economic aspects [61], but it only reaches the project level [62]. In contrast, the Strategic Environmental Assessment (SEA) is at the strategic level for, "the integration of environmental and social concerns in the process of developing policies, plans, or programs" [63,64]. Huang [65] proposed a theoretical framework of retrospective assessment approaches for SEA. In the transport sector, the European Commission enacted basic principles and key stages for SEA towards sustainability [66]; 
- Risk assessment: (1) The ISO 31000: risk management. This provides principles and guidelines as a general approach for risk assessment, which includes risk identification, risk analysis, and risk evaluation [67]; and (2) the ISO/IEC 31010: risk management. This recommends some useful techniques [68]. In addition, previous studies also recommended other methods for ecological and environmental risk assessment for strategic decision-making [49,51,69,70];

- Valuation: To integrate the interplay between shipping operational activities and multi-dimensional environment into decision-making processes, the Ecosystem Service Valuation (ESV) targeting the human welfare [71] is the most popular reference [72]. The values are generated by the prices from actual markets, surrogate market, and hypothetical market, including willingness-to-pay (WTP) [73-76]. It is beneficial for valuation of the impacts on location, resource, and society because of their socio-economic attributes and human subjective values [36]. However, as to the concept of green strategic planning in international shipping following eco-centrism and green development [2], the natural ecosystem has values in and for itself, irrespective of its utility for human beings [8]. Therefore, the concepts and methods of ESV are not good for valuation of the natural ecosystem. The concepts and methods of Ecosystem Intrinsic Valuation (EIV) have to be used in strategic decision-making processes for the evaluation of EIV [8,36,39]. Zhang et al. [36] and Sheng et al. [37] developed and applied the EIV in decision-making processes and made much progress. Thus, the EIV method is recommended to evaluate the impacts of environmental and ecological dimensions.

Table 2 summarizes a set of potential methods for international shipping green strategic planning. The proposed approach and methods follow the trend of door-to-door international shipping development, targeting green development, with beliefs of non-anthropocentrism and eco-centrism, and move gradually and continuously towards long-term sustainability. 
Table 2. Summary of the suggested green strategic planning methods for international shipping.

\begin{tabular}{|c|c|c|c|}
\hline Processes & Methods & Descriptions & Applications \\
\hline Decision-making & MDDM and its model of (I, C; R) & $\begin{array}{l}\text { A stepwise approach for strategic } \\
\text { decision-making process }\end{array}$ & $\begin{array}{l}\text { To provide a multi-dimensional approach and a model for } \\
\text { strategic decision-making processes in uncertain and complex } \\
\text { environments }\end{array}$ \\
\hline \multirow[t]{2}{*}{ Operational processes } & LCA in ISO 14000 & A highlight of life-cycle thinking & $\begin{array}{l}\text { To help the life-cycle of door-to-door international shipping } \\
\text { identification }\end{array}$ \\
\hline & EMS in ISO 14000 & A continual improvement process & $\begin{array}{l}\text { To help establish a cyclic approach and gradually move to the } \\
\text { long-term goal }\end{array}$ \\
\hline \multirow[t]{2}{*}{ Social assessment } & Public participation & Engaging public involvement in decision-making & $\begin{array}{l}\text { To identify and assess the imperceptible and unquantifiable } \\
\text { issues }\end{array}$ \\
\hline & Expert judgment & $\begin{array}{l}\text { A judgment based on the experts' knowledge and } \\
\text { experiences }\end{array}$ & $\begin{array}{l}\text { To identify and assess the imperceptible and unquantifiable } \\
\text { issues, and the decision-making processes }\end{array}$ \\
\hline \multirow{3}{*}{ Economic assessment } & Cost-effectiveness analysis & Cost-effective analysis & To assess the economic effectiveness \\
\hline & Cost-benefit analysis & Costs and benefits analysis & To assess the costs and benefits \\
\hline & Life-cycle cost analysis & Total costs analysis in the whole process & To assess the net present value of costs in the life-cycle \\
\hline \multirow{3}{*}{ Environmental assessment } & EIA & Environmental impact assessment of projects & $\begin{array}{l}\text { To analyze, predict, and evaluate the possible environmental } \\
\text { impacts at a project level }\end{array}$ \\
\hline & SEA & $\begin{array}{l}\text { Environmental impact assessment of policies, } \\
\text { plans, and programs }\end{array}$ & $\begin{array}{l}\text { To assess the environmental impacts on developing policies, } \\
\text { plans, and programs }\end{array}$ \\
\hline & Retrospective assessment & $\begin{array}{l}\text { Retrospective assessment of environmental } \\
\text { impacts }\end{array}$ & $\begin{array}{l}\text { To explore the trends of environment issues and identify the } \\
\text { accumulative effects in an attempt to find roots and mechanisms }\end{array}$ \\
\hline \multirow{3}{*}{ Risk assessment } & ISO 31000+ ISO/IEC 31010 & Risk assessment & To assess the risks with general process \\
\hline & Environmental Risk Assessment & Environmental risk assessment & To assess the environmental risks in strategic decision-making \\
\hline & Ecological Risk Assessment & Ecological risk assessment & To assess the ecological risks in strategic decision-making \\
\hline \multirow[t]{2}{*}{ Valuation } & ESV & Valuation of impacts & $\begin{array}{l}\text { To value the impacts on location, resource, and society } \\
\text { dimensions }\end{array}$ \\
\hline & EIV & Valuation of impacts & To value the impacts on the environment and ecology dimensions \\
\hline
\end{tabular}

Note: Such possible methods can be frequently updated in response to research and practical needs, in particular for assessment methods; MDDM: Multi-dimensional Decision-making; I: Impact; C: Confidence; R: Relationship; LCA: Life Cycle Assessment; ISO: International Organization for Standardization; EMS: Environmental Management System; EIA: Environmental Impact Assessment; SEA: Strategic Environmental Assessment; IEC: International Electro technical Commission; ESV: Ecosystem Service Valuation; EIV: Ecosystem Intrinsic Valuation. 


\section{Case Study}

\subsection{Overview}

Due to the growing deployment of larger vessels, the containerized trades allow the door-to-door supply chain construction in the shipping sector [23] and, hence, their impact on the environment can be separated. In view of this fact, this case study focused on a Chinese company importing wines from Italy to examine the approach and methods of green strategic planning designed for door-to-door international shipping. Specifically, CIELO E TERRA S.p.A. (a Joint Stock Company called "CIELO"), located in Montorso Vicentino, Vicenza, Veneto, Italy, exports wines to Xiamen Taila Import and Export Company Limited (called "TAILA"), located in Xiamen City, Fujian Province, China. The life-cycle of the door-to-door international shipping took place from 31 October 2016, to 20 December 2016, which included road transportation from CIELO to Port of Venice, marine transportation from Port of Venice via Port of Piraeus to Port of Xiamen, and road transportation from Port of Xiamen to TAILA. To implement the LCA approach from cradle-to-grave, we extended the process to front-end oriented vine planting and wine production, and back-end oriented wine sales, consumption, and waste disposal.

- Vine planting and wines production and storage: In this case study, grapes were planted in organic vineyards in Veneto and processed following the wine production procedures: harvesting and picking up $\rightarrow$ destemming and crushing $\rightarrow$ alcoholic and malolactic fermentation $\rightarrow$ aging (low-end wines are not required) $\rightarrow$ filtration $\rightarrow$ bottling $\rightarrow$ storage (aging in the bottles) $\rightarrow$ labeling $\rightarrow$ checking and testing $\rightarrow$ packing. During fermentation, high-end wines in oak barrels and low-end wines in stainless steel barrels were stored in a semi-finished area. The bottled aging wines were stored in the warehouse, and the packed wines were placed in a finished area;

- Road transportation from CIELO to Port of Venice: The 40-foot flat empty container was picked up on 31 October 2016. Then, the wines were carried to the container by a forklift. A heavy container weighing 21,409 $\mathrm{kg}$ was transported by trailer to Port of Venice on 2 November 2016. According to Google Maps, the distance was about $78.7 \mathrm{~km}$, which took 58 minutes and passed through farms, towns, parks, rivers, etc.;

- Operations in Port of Venice: When the container arrived at the Port of Venice on 2 November 2016, it was stacked by the onshore container crane to the front yard. On 4 November 2016, it was dispatched by truck. On 7 November 2016, the container was lifted onto the vessel ASIATIC MOON, a container ship;

- Maritime transportation from Port of Venice to Port of Piraeus: The ASIATIC MOON (built in October 2006; $150 \mathrm{~m}$ long, $22 \mathrm{~m}$ wide, $7.4 \mathrm{~m}$ in draft, and 9,978 $\mathrm{t}$ in terms of total tonnage [77]) started to sail from the Port of Venice on 7 November 2016, and arrived at the Port of Piraeus on 10 November 2016;

- Operations in Port of Piraeus: When the ship arrived at the Port of Piraeus on 10 November 2016, it was stacked by the onshore container crane and put in the front yard. On 17 November 2016, the container was uploaded onto the vessel YM WELLHEAD, a container ship;

- Maritime transportation from Port of Piraeus to Port of Xiamen: The vessel YM WELLHEAD (built in April 2014; $368 \mathrm{~m}$ in length, $51 \mathrm{~m}$ in width, $15 \mathrm{~m}$ in draft, and 144,651 $\mathrm{t}$ of total tonnage [77]) sailed from the Port of Piraeus on 17 November 2016, and arrived at the Port of Xiamen on 6 December 2016;

- Operations in Port of Xiamen: The YM WELLHEAD arrived at the Port of Xiamen on 6 December 2016, and then unloaded and stacked on the yard;

- Road transportation from Port of Xiamen to TAILA: On 19 December 2016, the container was transported by trailer from Port of Xiamen to the TAILA's warehouse. According to Google Map, the distance was about $28.6 \mathrm{~km}$, which would take 44 minutes by a truck. The empty container was returned to Port of Xiamen on 20 December 2016; 
- Storage and sale of wine in the TAILA, and disposal of waste: The packed wines were stacked in the warehouse of TAILA for about one year for Casaletto wine before a sale, and two to three years for Ripasso wines. The ratio of retail price to wholesale price was approximately 3:1. The Casaletto was sold for RMB $¥ 38$ (Chinese yuan) at wholesale price and RMB $¥ 98$ by retail, while Ripasso was sold for RMB $¥ 100$ at wholesale price and RMB $¥ 400$ by retail. None of the bottles were recycled.

\subsection{Data Collection}

The data collection methods were mentioned in Section 2.2, and the data sources are listed in Appendix A Table A1. For the trend analysis of the multi-dimensional assessment conducted in this study, the year of 2015 was taken as the baseline year for current situation assessment and the year of 2010 was used as the baseline year for retrospective assessment.

\subsection{Assessment}

The indicators used for regional multi-dimensional environmental assessment are listed in Table 3. They can be modified depending on a specific case.

\subsubsection{Regional Environment Retrospective and Current Status Assessment}

To understand the trends of regional environmental status and variation in the passing areas in the logistics flow, the current status and retrospective assessment of the regional environment are very useful for the identification and evaluation of environmental (accumulative) impacts and variation [65].

The results of the current status and retrospective assessment are summarized in Supplementary Materials I. Most of the dimensions in relevant regions showed good situations based on their assessment results. However, the results also indicate that Veneto is limited to natural resources, especially with respect to water and energy $[78,79]$, the Port of Venice is still confronted by some ecological problems associated with large benthic invertebrates and aquatic plants [80], and the Port of Xiamen has low biodiversity in phytoplankton and zooplankton and shows conflicts between port activities and natural reserves $[81,82]$. Nevertheless, there are no problem in the open oceans, although there may be some environmental problems in coastal waters, such as eutrophication.

\subsubsection{Life-Cycle Assessment}

Based on the life-cycle inventory of door-to-door international shipping (Table 1), we also tried to describe and assess the interaction between the operations of door-to-door shipping and six-dimensional environments related to logistics flow in the areas passed by. The detailed results are illustrated in Supplementary Materials II. Most of the results show that international shipping activities have positive impacts on the dimensions of society and economy, but negative impacts on resources, environment, and ecology. Employment and cost-benefit were identified as the main factors of social and economic concerns and, in the meantime, threatened natural reserves. Some sensitive areas require certain considerations.

On the other hand, the limited natural resources in Veneto will negatively impact the grape cultivation and production slightly, but rich renewable energy [79] plays an active role. The Venetian Lagoon, a United Nations Educational, Scientific and Cultural Organization (UNESCO) World Heritage site, seeks natural conservation, which is a challenge to the shipping activities in the Port of Venice. The natural reserves for endangered species, including Chinese white dolphin and Egrets, also limited shipping activities at the Port of Xiamen [82]. 
Table 3. Multi-dimensional indicators for the regional environmental assessment.

\begin{tabular}{|c|c|c|}
\hline Dimensions & Sub-Categories & Indicators \\
\hline \multirow{5}{*}{$\begin{array}{l}\text { Location (advantages and disadvantages compared } \\
\text { with the surrounding region) }\end{array}$} & Natural and Geographical & Geography, topography, landform, geology, climate, hydrology, soil, and groundwater, etc. \\
\hline & Resource location & Resource structure and resource sensitivity. \\
\hline & Social location & History, culture, and policy. \\
\hline & Economic location & Regional industries, markets, and economic hinterlands. \\
\hline & Ecological location & Ecological structure, function, and process. \\
\hline \multirow[t]{2}{*}{ Resources } & Natural resources & $\begin{array}{l}\text { Land, water, forest, energy, biological resources, including rare or endangered animals and } \\
\text { plants. }\end{array}$ \\
\hline & Humanistic resources & Culture, labor resources, transportation, and tourism resources. \\
\hline \multirow{8}{*}{ Society } & Political civilization & Policies, regulations, religion, ethics, social activities, public participation, and social security. \\
\hline & Family and household & $\begin{array}{l}\text { Population, proportion of migrants, labor, employment, income, consumption, prices, and } \\
\text { living environment. }\end{array}$ \\
\hline & Culture and art & Cultural lifestyle, language, traditional culture, humanities, and art. \\
\hline & News and communications & Information disclosure, media development, news topics, communication effects. \\
\hline & Medical and health & Medical facilities, health conditions, diseases. \\
\hline & Education and technology & $\begin{array}{l}\text { Education investment, education resources, investment and output in research and } \\
\text { development. }\end{array}$ \\
\hline & Administrative management & Management system and performance. \\
\hline & Infrastructure & $\begin{array}{l}\text { Infrastructures of transportation, business, entertainment and leisure, information and } \\
\text { communication, and landscaping. }\end{array}$ \\
\hline \multirow{6}{*}{ Economy } & Economic power & $\begin{array}{l}\text { GDP (gross domestic product), GDP growth rate, GDP per capita, industrial output value, } \\
\text { industrial output growth rate. }\end{array}$ \\
\hline & Industrial structure & $\begin{array}{l}\text { The output of the first, second, and third industries and their proportion, foreign investment, } \\
\text { outbound investment, transportation business, and environmental investment. }\end{array}$ \\
\hline & Fixed asset investment & $\begin{array}{l}\text { Total fixed assets investment, new fixed assets investment, and fixed assets investment in } \\
\text { transportation. }\end{array}$ \\
\hline & Trade and logistics & Total import and export volume, freight volume or throughput, and freight turnover. \\
\hline & Finance and taxation & Financial revenue, fiscal deficit, and taxes. \\
\hline & Monetary and insurance & Deposit and loan, capital flow, insurance amount, indemnity, and solvency. \\
\hline
\end{tabular}


Table 3. Cont

\begin{tabular}{lll}
\hline & \multicolumn{1}{c}{ Dimensions } & \multicolumn{1}{c}{ Indicators } \\
\hline \multirow{2}{*}{ Environment } & Air environment & Air quality, and atmospheric diffusion conditions. \\
\cline { 3 - 3 } & Water environment & Surface water, seawater, and groundwater quality, and hydrodynamic conditions. \\
\cline { 2 - 3 } & Acoustic environment & Equivalent sound level, over-standard rate. \\
\cline { 2 - 3 } & Solid waste & Sources, quantity, and solid waste management and disposal. \\
\cline { 2 - 3 } & Soil environment & Soil quality. \\
\cline { 2 - 3 } & Environmental risk & Environmental risk, which may be caused by oil spills or chemical leakage. \\
\cline { 2 - 3 } & Terrestrial ecosystems & Ecosystem health, biodiversity, habitat environment, vegetation cover, and species invasion. \\
\cline { 2 - 3 } & Aquatic ecosystems & Ecosystem health, biodiversity, habitat environment, species invasion. \\
\cline { 2 - 3 } & Sensitive bio-ecology & $\begin{array}{l}\text { Statutory protected species, nature reserves, rare or endangered animals and plants, and } \\
\text { endemic flora and fauna. }\end{array}$ \\
\cline { 2 - 3 } & Ecological risk & Ecological risk, which may be caused by oil spills or species invasion \\
\hline
\end{tabular}




\subsection{Strategic Decision-Making}

\subsubsection{Process of Strategic Decision-Making}

Based on the assessment results, strategic decisions were made by the experts' judgments using the MDDM model $(I, C ; R)$, following the four steps given in the MDDM approach [47]:

(1) Integrated assessment of the status for each dimension in each region: The scores of six dimensions of each region were made according to the experts' judgments, based on the results of retrospective and current status assessment, to understand the regional situations. Numbers 1, 2, and 3 were used to represent the integrated status of poor, medium, and good, respectively, as the indicators for sub-categories or dimensions in each region. Five experts (listed in Appendix A Table A2) were invited to participate in the integrated assessment during the decision-making processes;

(2) Impact assessment for LCA: The scores of the impacts of shipping activities in the life-cycle on the six dimensions of regional environments and the impacts of six regional dimensions on shipping activities were made based on the experts' judgments, according to the results of status evaluation and experts' experiences, following the approach and methods discussed in Section 3.2;

(3) Strategic decision-making: The interplay and relationships between shipping activities and the six dimensions of regional environments were made based on the experts' judgments using the MDDM model $(I, C ; R)$ following the approach and methods in Section 3.2. The comprehensive evaluation values $S_{i}^{j}$ and $S_{j}^{i}$ were calculated using Equation (1) and Equation (2). The results are given in Tables 4 and 5, which were generated based on all the experts' judgments and used for the door-to-door international shipping final decision-making;

(4) Greening development assessment: The green development levels in shipping activities and all dimensions of relevant regions were evaluated using values of 1, 2, and 3 to represent low, medium and high development levels, respectively [2], aligned with the ecosystem intrinsic value for maintenance and nature conservation [37].

\subsubsection{Result and Strategic Decision-Making Analysis}

Results from the strategic decision-making analysis show that the confidence levels varied, mostly ranging from 0.6 to 1 , with an average of 0.77 (Table 4 ) and 0.74 (Table 5), respectively, which were very close to each other among the five experts, with a high confidence level.

As for the shipping activity impact on the relevant regional environment (Table 4), the positive and negative judgments were relatively consistent, and the Relationship scores given by the experts agreed very well. The average comprehensive evaluation scores $(I \times C \times R)$ varied between -1.8 and 4.2. Regarding the impacts of relevant regional environments on shipping activities (Table 5), some experts gave different opinions on the positive and negative impacts and relationships. The average scores ranged from -4.5 to 7.2 , indicating a relatively wider variation than that in Table 4 . Nevertheless, the final decision was made by a majority vote among the experts.

According to the experts' judgments, we could rank the impact based on the absolute value of the comprehensive evaluation scores. The impact levels could be defined as slight, low, moderate, and significant when the scores were $<1,1-3,3-6$, and $>6$, respectively. Accordingly, the shipping activities showed slightly positive impacts on the dimensions of society and economy, and slightly negative impacts on the dimensions of resources, environment, and ecology, except for the wine production and storage in the CIELO factory, which showed a slightly positive impact (Table 4). As shown in Table 5, the dimensions of location, resources, society, and economy positively affected the shipping activities in most situations, but the dimensions of environment and ecology showed a slightly negative impact on the shipping activities. The activities of wine production, storage in the CIELO factory, and maritime transportation suffered from a slight positive impact. 
Table 4. Results of experts' judgments on the shipping activity impacts on relevant regional environments using the multi-dimensional decision-making (MDDM) model.

\begin{tabular}{|c|c|c|c|c|c|c|c|}
\hline Activities & Regional Environments & Expert 1 & Expert 2 & Expert 3 & Expert 4 & Expert 5 & Average Scores \\
\hline \multirow{6}{*}{ Wine production } & Location & $(0,0.9 ; 1)=0$ & $(1,0.7 ; 1)=0.7$ & $(0,0.7 ; 1)=0.7$ & $(0,0.6 ; 0)=0$ & $(0,1 ; 0)=0$ & 0.28 \\
\hline & Resource & $(-1,0.9 ; 1)=-0.9$ & $(1,0.7 ; 1)=0.7$ & $(-1,0.7 ; 1)=-0.7$ & $(-1,0.7 ; 2)=-1.4$ & $(-1,0.9 ; 1)=-0.9$ & -0.64 \\
\hline & Society & $(1,0.9 ; 1)=0.9$ & $(1,0.8 ; 1)=0.8$ & $(1,0.7 ; 1)=0.7$ & $(1,0.7 ; 2)=1.4$ & $(3,0.7 ; 2)=4.2$ & 1.6 \\
\hline & Economy & $(-1,0.8 ; 2)=-1.6$ & $(1,0.8 ; 1)=0.8$ & $(1,0.7 ; 1)=0.7$ & $(1,0.6 ; 2)=1.2$ & $(1,0.8 ; 1)=0.8$ & 0.38 \\
\hline & Environment & $(-1,0.8 ; 1)=-0.8$ & $(2,0.8 ; 2)=3.2$ & $(-1,0.7 ; 1)=-0.7$ & $(0,0.7 ; 2)=0$ & $(-1,0.7 ; 1)=-0.7$ & 0.2 \\
\hline & Ecology & $(-1,0.7 ; 1)=-0.7$ & $(2,0.8 ; 2)=3.2$ & $(0,0.7 ; 1)=0$ & $(0,0.6 ; 2)=0$ & $(0,1 ; 0)=0$ & 0.5 \\
\hline \multirow{6}{*}{ Storage in CIELO's factory } & Location & $(0,0.9 ; 1)=0$ & $(1,0.7 ; 1)=0.7$ & $(1,0.7 ; 1)=0.7$ & $(0,0.6 ; 2)=0$ & $(0,1 ; 0)=0$ & 0.28 \\
\hline & Resource & $(-1,0.8 ; 1)=-0.8$ & $(1,0.7 ; 2)=1.4$ & $(0,0.7 ; 1)=0$ & $(0,0.6 ; 1)=0$ & $(0,0.9 ; 0)=0$ & 0.12 \\
\hline & Society & $(1,0.9 ; 1)=0.9$ & $(1,0.8 ; 1)=0.8$ & $(0,0.7 ; 1)=0$ & $(1,0.7 ; 0)=0$ & $(0,0.9 ; 0)=0$ & 0.34 \\
\hline & Economy & $(1,0.9 ; 1)=0.9$ & $(1,0.8 ; 1)=0.8$ & $(0,0.7 ; 1)=0$ & $(1,0.6 ; 1)=0.6$ & $(1,0.9 ; 0)=0$ & 0.46 \\
\hline & Environment & $(-1,0.8 ; 1)=-0.8$ & $(1,0.8 ; 1)=0.8$ & $(0,0.7 ; 1)=0$ & $(0,0.7 ; 0)=0$ & $(0,0.9 ; 0)=0$ & 0 \\
\hline & Ecology & $(-1,0.7 ; 1)=-0.7$ & $(1,0.8 ; 1)=0.8$ & $(0,0.7 ; 1)=0$ & $(0,0.6 ; 0)=0$ & $(0,0.9 ; 0)=0$ & 0.02 \\
\hline \multirow{6}{*}{$\begin{array}{l}\text { Road transportation from } \\
\text { CIELO to Port of Venice }\end{array}$} & Location & $(1,0.9 ; 1)=0.9$ & $(1,0.7 ; 1)=0.7$ & $(0,0.7 ; 1)=0$ & $(0,0.6 ; 2)=0$ & $(0,1 ; 0)=0$ & 0.32 \\
\hline & Resource & $(-1,0.9 ; 1)=-0.9$ & $(1,0.7 ; 1)=0.7$ & $(-1,0.7 ; 1)=-0.7$ & $(-1,0.6 ; 2)=-1.2$ & $(-1,0.9 ; 1)=-0.9$ & -0.6 \\
\hline & Society & $(1,0.9 ; 1)=0.9$ & $(1,0.8 ; 1)=0.8$ & $(-1,0.7 ; 1)=-0.7$ & $(2,0.7 ; 1)=1.4$ & $(-1,0.9 ; 1)=-0.9$ & 0.3 \\
\hline & Economy & $(2,0.9 ; 2)=3.6$ & $(1,0.8 ; 1)=0.8$ & $(1,0.7 ; 1)=0.7$ & $(2,0.6 ; 2)=2.4$ & $(1,0.9 ; 1)=0.9$ & 1.68 \\
\hline & Environment & $(-1,0.9 ; 1)=-0.9$ & $(-1,0.8 ; 1)=-0.8$ & $(-1,0.8 ; 1)=-0.8$ & $(-1,0.7 ; 1)=-0.7$ & $(-1,0.9 ; 1)=-0.9$ & -0.82 \\
\hline & Ecology & $(-1,0.9 ; 2)=-1.8$ & $(-1,0.8 ; 1)=-0.8$ & $(-1,0.7 ; 1)=-0.7$ & $(-1,0.6 ; 1)=-0.6$ & $(-1,0.8 ; 1)=-0.8$ & -0.94 \\
\hline \multirow{6}{*}{ Operations in Port of Venice } & Location & $(0,0.9 ; 1)=0$ & $(0,0.8 ; 1)=0$ & $(0,0.7 ; 1)=0$ & $(0,0.6 ; 1)=0$ & $(0,1 ; 0)=0$ & 0 \\
\hline & Resource & $(-1,0.7 ; 1)=-0.7$ & $(-1,0.7 ; 1)=-0.7$ & $(-1,0.7 ; 1)=-0.7$ & $(0,0.7 ; 1)=0$ & $(-1,0.9 ; 1)=-0.9$ & -0.6 \\
\hline & Society & $(1,0.9 ; 1)=0.9$ & $(1,0.7 ; 1)=0.7$ & $(1,0.7 ; 1)=0.7$ & $(1,0.7 ; 2)=1.4$ & $(1,0.8 ; 1)=0.8$ & 0.9 \\
\hline & Economy & $(2,0.8 ; 2)=3.2$ & $(1,0.7 ; 1)=0.7$ & $(1,0.7 ; 1)=0.7$ & $(1,0.6 ; 2)=1.2$ & $(1,0.8 ; 1)=0.8$ & 1.32 \\
\hline & Environment & $(-1,0.8 ; 1)=-0.8$ & $(-1,0.9 ; 2)=-1.8$ & $(-1,0.8 ; 1)=-0.8$ & $(-1,0.7 ; 1)=-0.7$ & $(-1,0.7 ; 1)=-0.7$ & -0.96 \\
\hline & Ecology & $(-1,0.7 ; 1)=-0.7$ & $(-1,0.9 ; 2)=-1.8$ & $(-1,0.7 ; 1)=-0.7$ & $(-1,0.6 ; 1)=-0.6$ & $(-2,0.7 ; 2)=-2.8$ & -1.32 \\
\hline
\end{tabular}


Table 4. Cont

\begin{tabular}{|c|c|c|c|c|c|c|c|}
\hline Activities & Regional Environments & Expert 1 & Expert 2 & Expert 3 & Expert 4 & Expert 5 & Average Scores \\
\hline \multirow{6}{*}{$\begin{array}{l}\text { Operations in Port of } \\
\text { Piraeus }\end{array}$} & Location & $(0,0.9 ; 1)=0$ & $(0,0.8 ; 1)=0$ & $(0,0.8 ; 1)=0$ & $(0,0.6 ; 2)=0$ & $(0,1 ; 0)=0$ & 0 \\
\hline & Resource & $(-1,0.7 ; 1)=-0.7$ & $(-1,0.6 ; 1)=-0.6$ & $(-1,0.6 ; 1)=-0.6$ & $(0,0.7 ; 1)=0$ & $(-1,0.9 ; 1)=-0.9$ & -0.56 \\
\hline & Society & $(1,0.9 ; 1)=0.9$ & $(1,0.7 ; 1)=0.7$ & $(1,0.7 ; 1)=0.7$ & $(1,0.7 ; 1)=0.7$ & $(1,0.7 ; 1)=0.7$ & 0.74 \\
\hline & Economy & $(2,0.8 ; 1)=1.6$ & $(1,0.7 ; 1)=0.7$ & $(1,0.7 ; 1)=0.7$ & $(1,0.6 ; 1)=0.6$ & $(1,0.8 ; 1)=0.8$ & 0.88 \\
\hline & Environment & $(-1,0.8 ; 1)=-0.8$ & $(-1,0.8 ; 2)=-1.6$ & $(-1,0.8 ; 1)=-0.8$ & $(-1,0.7 ; 1)=-0.7$ & $(-1,0.7 ; 1)=-0.7$ & -0.92 \\
\hline & Ecology & $(-1,0.7 ; 1)=-0.7$ & $(-1,0.8 ; 1)=-0.8$ & $(-1,0.7 ; 1)=-0.7$ & $(-1,0.6 ; 1)=-0.6$ & $(-1,0.8 ; 1)=-0.8$ & -0.72 \\
\hline \multirow{6}{*}{$\begin{array}{l}\text { Operations in Port of } \\
\text { Xiamen }\end{array}$} & Location & $(0,0.9 ; 1)=0$ & $(0,0.7 ; 1)=0$ & $(0,0.7 ; 1)=0$ & $(0,0.7 ; 2)=0$ & $(0,1 ; 0)=0$ & 0 \\
\hline & Resource & $(-1,0.7 ; 1)=-0.7$ & $(-1,0.7 ; 1)=-0.7$ & $(-1,0.7 ; 1)=-0.7$ & $(0,0.8 ; 1)=0$ & $(-1,0.8 ; 1)=-0.8$ & -0.58 \\
\hline & Society & $(1,0.9 ; 1)=0.9$ & $(1,0.7 ; 1)=0.7$ & $(1,0.7 ; 1)=0.7$ & $(1,0.8 ; 1)=0.8$ & $(1,0.8 ; 1)=0.8$ & 0.78 \\
\hline & Economy & $(2,0.8 ; 1)=1.6$ & $(1,0.7 ; 2)=1.4$ & $(1,0.8 ; 1)=0.8$ & $(1,0.7 ; 2)=1.4$ & $(1,0.8 ; 1)=0.8$ & 1.2 \\
\hline & Environment & $(-1,0.8 ; 1)=-0.8$ & $(-1,0.9 ; 2)=-1.8$ & $(-1,0.8 ; 1)=-0.8$ & $(0,0.8 ; 1)=0$ & $(-2,0.7 ; 2)=-2.8$ & -1.24 \\
\hline & Ecology & $(1,0.7 ; 1)=0.7$ & $(-1,0.9 ; 1)=-0.9$ & $(-1,0.7 ; 1)=-0.7$ & $(-1,0.7 ; 1)=-0.7$ & $(-1,0.8 ; 1)=-0.8$ & -0.48 \\
\hline \multirow{3}{*}{ Maritime transportation } & Resource & $(0,0.8 ; 1)=0$ & $(-1,0.7 ; 1)=-0.7$ & $(-1,0.7 ; 1)=-0.7$ & $(0,0.6 ; 1)=0$ & $(0,0.6 ; 0)=0$ & -0.28 \\
\hline & Environment & $(0,0.8 ; 1)=0$ & $(-1,0.8 ; 2)=-1.6$ & $(-1,0.8 ; 1)=-0.8$ & $(0,0.7 ; 2)=0$ & $(0,0.8 ; 0)=0$ & -0.48 \\
\hline & Ecology & $(-1,0.7 ; 1)=-0.7$ & $(-1,0.8 ; 1)=-1.8$ & $(-1,0.7 ; 1)=-0.7$ & $(-1,0.7 ; 2)=-1.4$ & $(-2,0.7 ; 2)=-2.8$ & -1.48 \\
\hline \multirow{6}{*}{$\begin{array}{l}\text { Road transportation from } \\
\text { Port of Xiamen to TAILA }\end{array}$} & Location & $(1,0.9 ; 1)=0.9$ & $(0,0.7 ; 1)=0$ & $(0,0.8 ; 1)=0$ & $(0,0.7 ; 2)=0$ & $(0,1 ; 0)=0$ & 0.18 \\
\hline & Resource & $(-1,0.9 ; 2)=-1.8$ & $(-1,0.7 ; 1)=-0.7$ & $(-1,0.7 ; 1)=-0.7$ & $(0,0.7 ; 1)=0$ & $(-1,0.8 ; 1)=-0.8$ & -0.8 \\
\hline & Society & $(1,0.9 ; 2)=1.8$ & $(1,0.7 ; 1)=0.7$ & $(-1,0.7 ; 1)=-0.7$ & $(1,0.8 ; 1)=0.8$ & $(-1,0.8 ; 1)=-0.8$ & 0.36 \\
\hline & Economy & $(2,0.9 ; 2)=3.6$ & $(1,0.7 ; 2)=1.4$ & $(1,0.8 ; 1)=0.8$ & $(0,0.7 ; 1)=0$ & $(1,0.7 ; 1)=0.7$ & 1.3 \\
\hline & Environment & $(-1,0.9 ; 1)=-0.9$ & $(-1,0.9 ; 2)=-1.8$ & $(-1,0.8 ; 1)=-0.8$ & $(-1,0.8 ; 1)=-0.8$ & $(-1,0.8 ; 1)=-0.8$ & -1.02 \\
\hline & Ecology & $(-1,0.7 ; 1)=-0.7$ & $(-1,0.9 ; 2)=-1.8$ & $(-1,0.7 ; 1)=-0.7$ & $(-1,0.7 ; 1)=-0.7$ & $(0,1 ; 0)=0$ & -0.78 \\
\hline \multirow{6}{*}{$\begin{array}{l}\text { Storage in the TAILA's } \\
\text { warehouse }\end{array}$} & Location & $(0,0.9 ; 1)=0$ & $(0,0.7 ; 1)=0$ & $(0,0.8 ; 1)=0$ & $(0,0.7 ; 2)=0$ & $(0,1 ; 0)=0$ & 0 \\
\hline & Resource & $(-1,0.7 ; 1)=-0.7$ & $(-1,0.7 ; 1)=-0.7$ & $(-1,0.7 ; 1)=-0.7$ & $(-1,0.7 ; 0)=0$ & $(-1,1 ; 1)=-1$ & -0.62 \\
\hline & Society & $(1,0.9 ; 2)=1.8$ & $(1,0.7 ; 1)=0.7$ & $(0,0.7 ; 1)=0$ & $(1,0.8 ; 0)=0$ & $(0,1 ; 0)=0$ & 0.5 \\
\hline & Economy & $(1,0.9 ; 2)=1.8$ & $(1,0.7 ; 1)=0.7$ & $(0,0.7 ; 1)=0$ & $(0,0.7 ; 1)=0$ & $(0,0.9 ; 0)=0$ & 0.5 \\
\hline & Environment & $(-1,0.9 ; 1)=-0.9$ & $(-1,0.9 ; 1)=-0.9$ & $(0,0.7 ; 1)=-0$ & $(0,0.8 ; 0)=0$ & $(0,1 ; 0)=0$ & -0.36 \\
\hline & Ecology & $(-1,0.7 ; 1)=-0.7$ & $(-1,0.9 ; 1)=-0.9$ & $(0,0.7 ; 1)=-0$ & $(0,0.7 ; 0)=0$ & $(0,1 ; 0)=0$ & -0.32 \\
\hline
\end{tabular}


Table 5. Results of experts' judgments on the relevant regional environmental impact on shipping activities using the MDDM model.

\begin{tabular}{|c|c|c|c|c|c|c|c|}
\hline Activities & Regional Environments & Expert 1 & Expert 2 & Expert 3 & Expert 4 & Expert 5 & Average Scores \\
\hline \multirow{6}{*}{ Wine production } & Location & $(1,0.8 ; 1)=0.8$ & $(1,0.7 ; 1)=0.7$ & $(1,0.7 ; 1)=0.7$ & $(2,0.6 ; 1)=1.2$ & $(1,0.7 ; 1)=0.7$ & 0.82 \\
\hline & Resource & $(1,0.8 ; 1)=0.8$ & $(2,0.7 ; 2)=2.8$ & $(1,0.7 ; 1)=0.7$ & $(2,0.7 ; 3)=4.2$ & $(0,0.9 ; 0)=0$ & 1.7 \\
\hline & Society & $(1,0.9 ; 2)=1.8$ & $(1,0.7 ; 1)=0.7$ & $(1,0.7 ; 1)=0.7$ & $(1,0.7 ; 1)=0.7$ & $(2,0.8 ; 2)=3.2$ & 1.42 \\
\hline & Economy & $(1,0.8 ; 2)=1.6$ & $(1,0.7 ; 2)=1.4$ & $(1,0.8 ; 2)=1.6$ & $(1,0.6 ; 1)=0.6$ & $(2,0.6 ; 2)=2.4$ & 1.52 \\
\hline & Environment & $(1,0.9 ; 1)=0.9$ & $(1,0.8 ; 1)=0.8$ & $(1,0.8 ; 1)=-0.7$ & $(-1,0.7 ; 1)=-0.7$ & $(0,0.9 ; 0)=0$ & 0.06 \\
\hline & Ecology & $(1,0.7 ; 1)=0.7$ & $(1,0.8 ; 2)=1.6$ & $(1,0.8 ; 1)=0.8$ & $(-1,0.6 ; 1)=-0.6$ & $(0,0.8 ; 0)=0$ & 0.5 \\
\hline \multirow{6}{*}{$\begin{array}{l}\text { Storage in the CIELO's } \\
\text { factory }\end{array}$} & Location & $(0,0.9 ; 1)=0$ & $(1,0.7 ; 1)=0.7$ & $(1,0.7 ; 1)=0.7$ & $(1,0.6 ; 1)=0.6$ & $(1,0.7 ; 1)=0.7$ & 0.54 \\
\hline & Resource & $(-1,0.7 ; 1)=-0.7$ & $(1,0.8 ; 1)=0.8$ & $(1,0.8 ; 1)=0.8$ & $(-1,0.6 ; 1)=-0.6$ & $(0,0.9 ; 0)=0$ & 0.06 \\
\hline & Society & $(1,0.9 ; 1)=0.9$ & $(1,0.7 ; 1)=0.7$ & $(1,0.7 ; 1)=0.7$ & $(1,0.7 ; 1)=0.7$ & $(1,0.7 ; 1)=0.7$ & 0.74 \\
\hline & Economy & $(2,0.8 ; 2)=3.2$ & $(1,0.7 ; 1)=0.7$ & $(1,0.7 ; 1)=0.7$ & $(1,0.6 ; 1)=0.6$ & $(2,0.6 ; 2)=2.4$ & 1.52 \\
\hline & Environment & $(1,0.9 ; 1)=0.9$ & $(0,0.8 ; 1)=0$ & $(0,0.8 ; 1)=0$ & $(0,0.7 ; 0)=0$ & $(-1,0.5 ; 1)=-0.5$ & 0.28 \\
\hline & Ecology & $(1,0.8 ; 1)=0.8$ & $(0,0.8 ; 1)=0$ & $(0,0.8 ; 1)=0$ & $(0,0.6 ; 0)=0$ & $(-1,0.8 ; 1)=-0.8$ & 0 \\
\hline \multirow{6}{*}{$\begin{array}{l}\text { Road transportation from } \\
\text { CIELO to Port of Venice }\end{array}$} & Location & $(1,0.9 ; 1)=0.9$ & $(1,0.7 ; 1)=0.7$ & $(1,0.7 ; 1)=0.7$ & $(1,0.6 ; 1)=0.6$ & $(2,0.8 ; 2)=3.2$ & 1.22 \\
\hline & Resource & $(2,0.9 ; 2)=3.6$ & $(1,0.7 ; 1)=0.7$ & $(1,0.7 ; 1)=0.7$ & $(1,0.6 ; 1)=0.6$ & $(0,0.9 ; 0)=0$ & 1.12 \\
\hline & Society & $(2,0.9 ; 1)=1.8$ & $(1,0.7 ; 1)=0.7$ & $(1,0.7 ; 1)=0.7$ & $(2,0.7 ; 1)=1.4$ & $(3,0.8 ; 3)=7.2$ & 2.36 \\
\hline & Economy & $(2,0.9 ; 2)=3.6$ & $(1,0.7 ; 1)=0.7$ & $(1,0.7 ; 1)=0.7$ & $(2,0.6 ; 1)=1.2$ & $(3,0.8 ; 3)=7.2$ & 2.68 \\
\hline & Environment & $(-1,0.9 ; 1)=-0.9$ & $(-1,0.8 ; 2)=-1.6$ & $(-1,0.8 ; 2)=-1.6$ & $(0,0.7 ; 1)=0$ & $(-1,0.6 ; 1)=-0.6$ & -0.94 \\
\hline & Ecology & $(1,0.8 ; 1)=0.8$ & $(-1,0.8 ; 1)=-0.8$ & $(-1,0.8 ; 1)=-0.8$ & $(0,0.6 ; 1)=0$ & $(-1,0.8 ; 1)=-0.8$ & -0.32 \\
\hline \multirow{6}{*}{ Operations in Port of Venice } & Location & $(1,0.8 ; 1)=0.8$ & $(1,0.8 ; 1)=0.8$ & $(1,0.7 ; 1)=0.8$ & $(1,0.6 ; 1)=0.6$ & $(3,0.8 ; 2)=4.8$ & 1.56 \\
\hline & Resource & $(1,0.8 ; 1)=0.8$ & $(1,0.8 ; 1)=0.8$ & $(-1,0.7 ; 1)=-0.7$ & $(1,0.7 ; 2)=1.4$ & $(-1,0.7 ; 3)=-2.1$ & 0.04 \\
\hline & Society & $(1,0.9 ; 2)=1.8$ & $(1,0.7 ; 1)=0.7$ & $(1,0.7 ; 1)=0.7$ & $(1,0.7 ; 1)=0.7$ & $(3,0.7 ; 2)=4.2$ & 1.62 \\
\hline & Economy & $(1,0.9 ; 2)=1.8$ & $(1,0.7 ; 1)=0.7$ & $(1,0.7 ; 1)=0.7$ & $(0,0.6 ; 2)=0$ & N/A & 0.25 \\
\hline & Environment & $(1,0.9 ; 1)=0.9$ & $(-1,0.8 ; 1)=-0.8$ & $(-1,0.7 ; 1)=-0.7$ & $(0,0.7 ; 1)=0$ & $(-3,0.5 ; 3)=-4.5$ & -1.02 \\
\hline & Ecology & $(1,0.8 ; 1)=0.8$ & $(-1,0.8 ; 1)=-0.8$ & $(-1,0.7 ; 1)=-0.7$ & $(-1,0.6 ; 2)=-1.2$ & $(-2,0.5 ; 2)=-2$ & -0.78 \\
\hline
\end{tabular}


Table 5. Cont

\begin{tabular}{|c|c|c|c|c|c|c|c|}
\hline Activities & Regional Environments & Expert 1 & Expert 2 & Expert 3 & Expert 4 & Expert 5 & Average Scores \\
\hline \multirow{6}{*}{$\begin{array}{l}\text { Operations in Port of } \\
\text { Piraeus }\end{array}$} & Location & $(1,0.8 ; 1)=0.8$ & $(1,0.8 ; 1)=0.8$ & $(1,0.7 ; 1)=0.7$ & $(2,0.6 ; 1)=1.2$ & $(3,0.8 ; 3)=7.2$ & 2.14 \\
\hline & Resource & $(1,0.8 ; 1)=0.8$ & $(1,0.7 ; 1)=0.7$ & $(1,0.7 ; 1)=0.7$ & $(1,0.7 ; 1)=0.7$ & $(3,0.7 ; 3)=6.3$ & 1.84 \\
\hline & Society & $(1,0.9 ; 2)=1.8$ & $(1,0.7 ; 1)=0.7$ & $(1,0.7 ; 1)=0.7$ & $(1,0.7 ; 1)=0.7$ & $(3,0.6 ; 3)=5.4$ & 1.86 \\
\hline & Economy & $(1,0.9 ; 2)=1.8$ & $(1,0.7 ; 1)=0.7$ & $(1,0.7 ; 1)=0.7$ & $(0,0.6 ; 2)=0$ & $(3,0.5 ; 3)=4.5$ & 1.54 \\
\hline & Environment & $(1,0.9 ; 1)=0.9$ & $(-1,0.8 ; 1)=-0.8$ & $(-1,0.7 ; 1)=-0.7$ & $(0,0.7 ; 1)=0$ & $(-3,0.8 ; 3)=-4.5$ & -1.02 \\
\hline & Ecology & $(1,0.8 ; 1)=0.8$ & $(-1,0.8 ; 1)=-0.8$ & $(-1,0.6 ; 1)=-0.6$ & $(0,0.6 ; 1)=0$ & $(-2,0.7 ; 2)=-2.8$ & -0.68 \\
\hline \multirow{6}{*}{$\begin{array}{l}\text { Operations in Port of } \\
\text { Xiamen }\end{array}$} & Location & $(1,0.8 ; 1)=0.8$ & $(1,0.7 ; 1)=0.7$ & $(1,0.7 ; 1)=0.7$ & $(2,0.7 ; 2)=2.8$ & $(2,0.6 ; 2)=2.4$ & 1.48 \\
\hline & Resource & $(1,0.8 ; 1)=0.8$ & $(1,0.7 ; 1)=0.7$ & $(1,0.7 ; 1)=0.7$ & $(1,0.8 ; 1)=0.8$ & $(2,0.7 ; 2)=2.8$ & 1.16 \\
\hline & Society & $(1,0.9 ; 1)=0.9$ & $(1,0.7 ; 1)=0.7$ & $(1,0.7 ; 1)=0.7$ & $(1,0.8 ; 1)=0.8$ & $(3,0.8 ; 3)=7.2$ & 2.06 \\
\hline & Economy & $(1,0.9 ; 1)=0.9$ & $(1,0.7 ; 2)=1.4$ & $(1,0.7 ; 1)=0.7$ & $(1,0.7 ; 2)=1.4$ & $(2,0.6 ; 2)=2.4$ & 1.36 \\
\hline & Environment & $(1,0.9 ; 1)=0.9$ & $(-1,0.9 ; 2)=-1.8$ & $(-1,0.8 ; 1)=-0.8$ & $(-1,0.8 ; 1)=-0.8$ & $(-3,0.5 ; 3)=-4.5$ & -1.4 \\
\hline & Ecology & $(1,0.8 ; 1)=0.8$ & $(-1,0.9 ; 2)=-1.8$ & $(-1,0.7 ; 1)=-0.7$ & $(-1,0.7 ; 1)=-0.7$ & $(-2,0.7 ; 2)=-2.8$ & -1.04 \\
\hline \multirow{3}{*}{ Maritime transportation } & Resource & $(1,0.8 ; 1)=0.8$ & $(1,0.8 ; 1)=0.8$ & $(1,0.7 ; 1)=0.7$ & $(2,0.8 ; 3)=4.8$ & $(1,0.4 ; 3)=1.2$ & 1.66 \\
\hline & Environment & $(1,0.8 ; 1)=0.8$ & $(1,0.9 ; 2)=1.8$ & $(1,0.8 ; 1)=0.8$ & $(0,0.8 ; 1)=0$ & $(-1,0.6 ; 1)=-0.6$ & 0.56 \\
\hline & Ecology & $(1,0.7 ; 1)=0.7$ & $(1,0.9 ; 2)=1.8$ & $(1,0.7 ; 1)=0.7$ & $(-1,0.8 ; 1)=-0.8$ & $(-1,0.5 ; 1)=-0.5$ & 0.18 \\
\hline \multirow{6}{*}{$\begin{array}{l}\text { Road transportation from } \\
\text { Port of Xiamen to TAILA }\end{array}$} & Location & $(1,0.9 ; 1)=0.9$ & $(1,0.7 ; 1)=0.7$ & $(1,0.7 ; 1)=0.7$ & $(1,0.7 ; 2)=1.4$ & $(3,0.8 ; 3)=7.2$ & 2.18 \\
\hline & Resource & $(2,0.9 ; 2)=3.6$ & $(-1,0.7 ; 1)=-0.7$ & $(-1,0.7 ; 1)=-0.7$ & $(1,0.7 ; 1)=0.7$ & $(2,0.8 ; 2)=3.2$ & 1.22 \\
\hline & Society & $(2,0.9 ; 1)=1.8$ & $(1,0.7 ; 1)=0.7$ & $(1,0.7 ; 1)=0.7$ & $(2,0.8 ; 1)=1.6$ & $(3,0.7 ; 3)=6.3$ & 2.22 \\
\hline & Economy & $(2,0.9 ; 2)=3.6$ & $(1,0.7 ; 1)=0.7$ & $(1,0.8 ; 1)=0.8$ & $(2,0.7 ; 1)=1.4$ & $(3,0.8 ; 3)=7.2$ & 2.74 \\
\hline & Environment & $(-1,0.9 ; 1)=-0.9$ & $(-1,0.9 ; 1)=-0.9$ & $(-1,0.8 ; 1)=-0.8$ & $(-1,0.8 ; 1)=-0.8$ & $(-1,0.8 ; 1)=-0.8$ & -0.84 \\
\hline & Ecology & $(-1,0.8 ; 1)=-0.8$ & $(-1,0.9 ; 1)=-0.9$ & $(0,0.7 ; 1)=0$ & $(-1,0.7 ; 1)=-0.7$ & $(-1,0.8 ; 1)=-0.8$ & -0.64 \\
\hline \multirow{6}{*}{$\begin{array}{l}\text { Storage in the TAILA's } \\
\text { warehouse }\end{array}$} & Location & $(0,0.9 ; 1)=0$ & $(1,0.7 ; 1)=0.7$ & $(1,0.7 ; 1)=0.7$ & $(1,0.7 ; 2)=1.4$ & $(1,0.8 ; 1)=0.8$ & 0.72 \\
\hline & Resource & $(-1,0.7 ; 1)=-0.7$ & $(-1,0.7 ; 1)=-0.7$ & $(-1,0.7 ; 1)=-0.7$ & $(0,0.7 ; 2)=0$ & $(1,0.8 ; 1)=0.8$ & -0.26 \\
\hline & Society & $(1,0.9 ; 1)=0.9$ & $(1,0.7 ; 1)=0.7$ & $(1,0.7 ; 1)=0.7$ & $(1,0.8 ; 0)=0$ & $(2,0.5 ; 2)=2$ & 0.86 \\
\hline & Economy & $(2,0.8 ; 2)=3.2$ & $(1,0.7 ; 2)=1.4$ & $(1,0.7 ; 1)=0.7$ & $(2,0.7 ; 1)=1.4$ & $(1,0.5 ; 1)=0.5$ & 1.44 \\
\hline & Environment & $(1,0.9 ; 1)=0.9$ & $(-1,0.9 ; 1)=-0.9$ & $(0,0.7 ; 1)=0$ & $(0,0.8 ; 0)=0$ & $(-1,0.8 ; 1)=-0.8$ & -0.16 \\
\hline & Ecology & $(1,0.8 ; 1)=0.8$ & $(-1,0.9 ; 1)=-0.9$ & $(0,0.7 ; 1)=0$ & $(0,0.7 ; 0)=0$ & $(0,0.9 ; 0)=0$ & -0.02 \\
\hline
\end{tabular}


The assessment results of the green development level are shown in Table 6. Due to the large space, the results of the green evaluation of the environmental dimension are not listed. Most of the green development levels of shipping operations evaluated by the experts were the same, with a few exceptions. Therefore, we had reliable and effective expert judgments with good consistency. The green development levels of each shipping activity were all in the middle or upper level, of which wine production and operation in Port of Piraeus were at the highest level, while sale, consumption, and disposal of wine products were at the lowest level.

Table 6. Results of judgments by experts on the green development levels of shipping activities (extending to grape planting, wine production, consumption, and waste disposal).

\begin{tabular}{|c|c|c|c|c|c|c|}
\hline \multirow{2}{*}{ Activities } & \multicolumn{6}{|c|}{ Evaluation } \\
\hline & Expert 1 & Expert 2 & Expert 3 & Expert 4 & Expert 5 & Average Scores \\
\hline Vine planting & 3 & 3 & 3 & 3 & 3 & 3 \\
\hline Storage in the CIELO factory & 2 & 2 & 2 & 2 & 2 & 2 \\
\hline Road transportation from CIELO to Port of Venice & 2 & 2 & 2 & 2 & 2 & 2 \\
\hline Operations in Port of Piraeus & 2 & 3 & 3 & 3 & 2 & 2.6 \\
\hline Operations in Port of Xiamen & 3 & 2 & 2 & 2 & 3 & 2.4 \\
\hline Maritime transportation & 3 & 2 & 2 & 2 & 2 & 2.2 \\
\hline Road transportation from Port of Xiamen to TAILA & 2 & 2 & 2 & 2 & 2 & 2 \\
\hline
\end{tabular}

\subsection{Green Strategic Planning and Continual Improvement}

\subsubsection{International Shipping}

The green strategic planning for the door-to-door international shipping of CIELO wines can be organized as below:

- Vision: Follow the development trend of international shipping and meet the need of sustainability;

- Goal: Ensure that all activities in the door-to-door international shipping life-cycle satisfy the requirements of green development;

- Contents: Continually improve all activities in the life-cycle of door-to-door international shipping to approach green development;

- Planning:

(1) Define the life-cycle of the door-to-door international shipping of wines from CIELO to TAILA, as discussed in Section 4.1;

(2) Assess the interactions between operational activities of the door-to-door international shipping and regional environment from a multi-dimensional perspective;

(3) Identify the green development level of the activities and the regional environment; and

(4) Request to continually improve all activities of door-to-door international shipping to reduce the negative impacts on all dimensions of the regional environment, to achieve green development.

Based on the strategic decision-making results, we can propose to measure continual improvement of CIELO wine international shipping activities to reduce the negative impacts on the regional environment and raise their green development levels, in this case, to move towards sustainability. Recommendations for continual improvement are given in Table 7, which will help the next operation cycle. 
Table 7. Recommendations for CIELO wine international shipping improvement.

\begin{tabular}{|c|c|}
\hline Activities & Continual Improvements \\
\hline Vine planting & Continually working on organic viticulture. \\
\hline Wine production & $\begin{array}{l}\text { Continually reducing energy consumption, increasing clean } \\
\text { energy usage, reducing environmental impacts, and maintaining } \\
\text { the industry-leading levels. }\end{array}$ \\
\hline Storage in CIELO's factory & Inventory optimization and land resource consumption reduction. \\
\hline Road transportation from CIELO to Port of Venice & $\begin{array}{l}\text { Continually increasing energy efficiency, reducing exhaust } \\
\text { emissions and traffic noise, and avoiding the impacts on birds' } \\
\text { habitats and animal corridors. }\end{array}$ \\
\hline Operations in Port of Venice & $\begin{array}{l}\text { Continually increasing the energy efficiency and clean energy } \\
\text { usage, reducing exhaust emissions and conflicts to sensitive } \\
\text { ecology, and preventing the risks of an oil spill and species } \\
\text { invasion. }\end{array}$ \\
\hline Operations in Port of Piraeus & $\begin{array}{l}\text { Continually optimizing the container scheduling, restricting the } \\
\text { docking of old ships, reducing the exhaust emissions and noise, } \\
\text { and preventing the risks of an oil spill and species invasion. }\end{array}$ \\
\hline Maritime transportation & $\begin{array}{l}\text { Using new ships, continually increasing the ships energy efficiency, } \\
\text { reducing the exhaust emissions, prohibiting garbage entering the } \\
\text { sea, and reducing the conflicts to sensitive ecology. }\end{array}$ \\
\hline Operations in Port of Xiamen & $\begin{array}{l}\text { Continually increasing the energy efficiency and clean energy } \\
\text { usage, reducing exhaust emissions and noise, avoiding conflicts to } \\
\text { sensitive species, and preventing the risks of an oil spill and } \\
\text { species invasion. }\end{array}$ \\
\hline Road transportation from Port of Xiamen to TAILA & $\begin{array}{l}\text { Continually increasing energy efficiency, reducing exhaust } \\
\text { emissions and noise, and avoiding interfering with the ecological } \\
\text { sensitive areas. }\end{array}$ \\
\hline Storage in TAILA's warehouse & $\begin{array}{l}\text { Reasonably arranging sales, and reducing the occupation of land } \\
\text { resources. }\end{array}$ \\
\hline Sale, consumption, and disposal of wines & Recycling the wine bottles. \\
\hline
\end{tabular}

\subsubsection{For the Regional Environment}

Because the regional environment showed a direct impact on international shipping green development, we offer suggestions on continual improvement and green strategic planning for the regional environment to promote regional green development that will benefit international shipping. These include: (1) identifying the issues related to the regional environment and their impacts on international shipping based on the assessment (Section 4.3.1) and results of strategic decision-making (Section 4.4); (2) proposing measurements of continual improvement for regional environment from a multi-dimensional perspective; and (3) promoting regional green development to benefit international shipping. These recommendations are listed in Table 8, which will be used in the next case study.

\subsection{Discussion of the Case Study}

It was found from the case study results that the proposed approach and methods for the international shipping green strategic planning have several advantages: (1) they are applicable to door-to-door international shipping, can be used to evaluate the whole life-cycle of the logistics supply chain, and meet the development trend of the shipping industry; (2) they abide by the nature-centered principle and ecosystem intrinsic value [2] to follow green development and guide shipping towards sustainability; (3) they apply the MDDM approach for strategic decision-making to overcome the inherent weakness in MCDM, and push shipping development towards the long-term goal of sustainability; (4) they apply life-cycle thinking and continual improvement in ISO 14000 to meet the needs of the door-to-door logistics and green development; and (5) the planning process is at the strategic level by translating the long-term green development goal into development strategies, rather than passively responding to specific environmental problems. 
Table 8. Continual improvement recommendations for regional environment.

\begin{tabular}{ll}
\hline Regions & Continual Improvements \\
\hline Veneto City & $\begin{array}{l}\text { Continually reducing traffic congestion, improving the ambient air quality and acoustic } \\
\text { environment, avoiding interfering with the sensitive ecology, and preventing risks and } \\
\text { disasters. }\end{array}$ \\
\hline Port of Venice & $\begin{array}{l}\text { Continually reducing the emissions of NOX(nitrogen oxide), PM(particulate matter), } \\
\text { polycyclic aromatic hydrocarbons and inorganic nitrogen, avoiding oxygen-poor, } \\
\text { increasing the port waste collection, reducing the impacts on special flora and fauna in } \\
\text { the Venetian lagoon, and preventing the risks of an oil spill and species invasion. }\end{array}$ \\
\hline Port of Piraeus & $\begin{array}{l}\text { Continually improving the ambient air quality, strengthening the port waste } \\
\text { management, avoiding the conflicts between shipping and sensitive ecology and } \\
\text { maritime archaeological sites, and preventing the risks of an oil spill and species invasion. }\end{array}$ \\
\hline Port of Xiamen & $\begin{array}{l}\text { Continually reducing the emissions of carbon, PM10, and traffic noise, and the nutrient } \\
\text { levels in waters, protecting the biodiversity, avoiding conflicts between shipping and } \\
\text { sensitive organisms, and preventing the risks of an oil spill and species invasion. }\end{array}$ \\
\hline Xiamen City & $\begin{array}{l}\text { Continually improving the ambient air quality and acoustic environment, avoiding } \\
\text { interference with sensitive ecology, and preventing potential risks and disasters. }\end{array}$ \\
\hline
\end{tabular}

By applying the proposed approach and methods to this case study, it has not only indicated common environmental problems, such as energy efficiency, emissions, noise, ship oil spills, and endangered species, but also identifies the issues associated with shoreline and land resource uses, biodiversity loss, risks of species invasion, natural disasters and accidents, saltwater intrusion, and clean energy consumption, which are all green development key issues that are easily ignored.

\section{Discussion}

The framework and methodology for green strategic planning of door-to-door international shipping have made much progress, such as: (1) for the first time, it drafted a plan for door-to-door international shipping; (2) it integrated green development and its principles into the planning of international shipping after defining the concept of green development; (3) it applied the MDDM strategic decision-making approach to the international shipping strategic planning to reach the long-term goal of sustainability, rather than passive and fragmented environmental management; and (4) it combined life-cycle thinking with continual improvement in ISO 14000 for the first time, to meet the needs of the door-to-door logistics and dynamic green development processes, respectively.

The connotations of the proposed approach and methods for green strategic planning include insisting on a nature-first principle, adapting to door-to-door changing, using a top-down strategic decision-making approach, applying holistic methods for assessment, and integrating ISO 14000 concepts and methods into strategic planning.

However, big data acquisition and experts' judgments remain some challenges. Application of technologies such as the Internet of Things [83] and big data analysis may assist in international shipping green strategic planning. Furthermore, the application of ecosystem intrinsic value may still encounter some difficulties [37].

\section{Conclusions}

International shipping has been transformed from port-to-port operations to door-to-door services in the current context of globalization, larger-sized ships, and technological development. The world's shipping communities recently made their commitments to sustainability and were becoming more concerned with the implementation of the UN's SDGs. The approach and methods proposed in this study for door-to-door international shipping green strategic planning: (1) adapt to the development trend of the shipping industry of door-to-door international shipping services in the context of globalization; (2) follow the green development concept to reach sustainability; and (3) use strategic 
decision-making for shipping development, aiming at the long-term goal of sustainability. Through the case study, we acknowledged that the proposed approach and methods for door-to-door international shipping green strategic planning are suitable for the life-cycle in the logistics supply chain. This application not only indicated common environmental problems but identified the issues with green development to promote shipping development towards the long-term goal of sustainability.

Key barriers still exist in data accessibility and expert participation. Advanced technologies, such as big data, the Internet of Things, and Blockchain, are still needed to help data acquisition and build a collaborative and operative research-practice network in future. The proposed systematic approach and methods can be improved in the future for a broad application to other industries.

Supplementary Materials: The following are available online at http://www.mdpi.com/2071-1050/12/1/41/s1, Table S1-1: Location conditions of Veneto, Table S1-2: Resource conditions of Veneto, Table S1-3: Social conditions of Veneto, Table S1-4: Economic conditions of Veneto, Table S1-5: Environmental conditions of Veneto, Table S1-6: Ecological conditions of Veneto, Table S1-7: Location conditions of Port of Venice, Table S1-8: Resource conditions of Port of Venice, Table S1-9: Social conditions of Port of Venice, Table S1-10: Economic conditions of Port of Venice, Table S1-11: Environmental conditions of Port of Venice, Table S1-12: Ecologic conditions of Port of Venice, Table S1-13: Local conditions of Port of Piraeus, Table S1-14: Resource conditions of Port of Piraeus, Table S1-15: Social conditions of Port of Piraeus, Table S1-16: Economic conditions of Port of Piraeus, Table S1-17: Environmental conditions of Port of Piraeus, Table S1-18: Ecological conditions of Port of Piraeus, Table S1-19: Resources in the Pacific Ocean, Table S1-20: Environmental status of Pacific Ocean, Table S1-21: Ecological conditions of Pacific Ocean, Table S1-22: Resource conditions of the Indian Ocean, Table S1-23: Environmental conditions of the Indian Ocean, Table S1-24: Ecological conditions of Indian Ocean, Table S1-25: Resource in the Atlantic Ocean, Table S1-26: Environmental status of Atlantic Ocean, Table S1-27: Ecological conditions of Atlantic Ocean, Table S1-28: Location setting of Port of Xiamen, Table S1-29: Resource conditions of Port of Xiamen, Table S1-30: Social status of Port of Xiamen, Table S1-31: Economic status of Port of Xiamen, Table S1-32: Environmental conditions of Port of Xiamen, Table S1-33: Ecological conditions of Port of Xiamen, Table S1-34: Location setting of Xiamen, Table S1-35: Resource conditions of Xiamen, Table S1-36: Social status of Xiamen, Table S1-37: Economic status of Xiamen, Table S1-38: Environmental conditions of Xiamen, Table S1-39: Ecological conditions of Xiamen, Table S2-1: Assessment of wine production, Table S2-2: Assessment of road transportation in Veneto, Table S2-3: Assessment of Port of Venice operations, Table S2-4: Assessment of Port of Piraeus operations, Table S2-5: Assessment of maritime transportation, Table S2-6: Assessment of Port of Xiamen operations, Table S2-7: Assessment of road transportation in Xiamen.

Author Contributions: L.Z. designed and oversaw the research. X.W. collected information and drafted the manuscript. H.F. participated in the investigation. All the authors edited the manuscript. All authors have read and agreed to the published version of the manuscript.

Funding: This research was supported in part by the National Public Welfare Research Project of State Oceanic Administration of China (Grant \#200905005) and the Jimei University (Scientific Research Starting Foundation \#ZQ2019037).

Acknowledgments: We are grateful to three anonymous reviewers whose informative comments and suggestions improved an early version of this manuscript.

Conflicts of Interest: The authors declare no conflict of interest.

\section{Appendix A}

Table A1. Selected data sources for the case study.

\begin{tabular}{cl}
\hline \multicolumn{1}{c}{ Sources } & \multicolumn{1}{c}{ Details } \\
\hline \multirow{3}{*}{ Interview and survey } & $\begin{array}{l}\text { The TAILA company and the road transportation in Xiamen were visited to understand } \\
\text { the current situation of storage and sales of wines in TAILA and road transportation in } \\
\text { Xiamen region, and the Xiamen Port Authority was interviewed to help understand the } \\
\text { operations in Port of Xiamen. }\end{array}$ \\
\hline Literature search & $\begin{array}{l}\text { The keywords of "Veneto", "Port of Venice", "Port of Piraeus", "Port of Xiamen", and } \\
\text { "Xiamen" were used to search for information from databases for understanding their } \\
\text { current status. }\end{array}$ \\
\hline
\end{tabular}


Table A1. Cont.

\begin{tabular}{cl}
\hline \multicolumn{1}{c}{ Sources } & \multicolumn{1}{c}{ Details } \\
\hline & Statistic yearbooks, reports, political documents, planning, etc. were collected by \\
& searching official websites, including CIELO E TERRA S.p.A. \\
& http://www.cieloeterravini.com/en-UK/home-page.php, Regional Agency for \\
& Environmental Prevention and Protection of Veneto \\
& http://www.wine-world.com/area/italy/veneto, Port of Venice \\
& https://www.port.venice.it/en, North Adriatic Sea Port Association \\
& http://www.portsofnapa.com/, Port of Piraeus http://www.olp.gr/en/, Hellenic \\
Official websites access & Statistical Authority http://www.statistics.gr/en/home, IMO \\
& http://www.imo.org/EN/Pages/Default.aspx, Trans-boundary Waters Assessment \\
& Programme http://geftwap.org/, the Joint Group of Experts on the Scientific Aspects of \\
& Marine Environmental Protection \\
& http://www.gesamp.org/publications/pollution-in-the-open-oceans, EcoTransIT World \\
& https://www.ecotransit.org/calculation.en.html, Secretariat of the Pacific Environment \\
& Programme https://www.sprep.org/, Port of Xiamen http://www.portxiamen.gov.c, and \\
& Xiamen Municipal Government http://www.xm.gov.cn/. \\
\hline
\end{tabular}

Table A2. List of the invited experts who participated in the case study.

\begin{tabular}{cl}
\hline Experts & \multicolumn{1}{c}{ Details } \\
\hline Expert A & $\begin{array}{l}\text { Shengyun Yang, retired professor, the College of Ocean and Earth Sciences, Xiamen University, } \\
\text { whose background is in integrated coastal management and ecosystem-based marine } \\
\text { management. }\end{array}$ \\
\hline Expert B & $\begin{array}{l}\text { Luoping Zhang, retired professor, the Coastal and Ocean Management Institute, Xiamen } \\
\text { University, whose background is in environmental management. }\end{array}$ \\
\hline Expert C & $\begin{array}{l}\text { Weiqi Chen, retired professor, the College of the Environment and Ecology, Xiamen University, } \\
\text { whose background is in resource and environmental economics. }\end{array}$ \\
\hline Expert D & $\begin{array}{l}\text { Qinhua Fang, professor, the Coastal and Ocean Management Institute, Xiamen University, whose } \\
\text { background is in environmental system assessment, marine spatial planning, and marine policy. }\end{array}$ \\
\hline \multirow{2}{*}{ Expert E } & $\begin{array}{l}\text { Yangfan Li, professor, the College of the Environment and Ecology, Xiamen University, whose } \\
\text { background is in coastal landscape ecology, ecological environment planning and ecological } \\
\text { civilization. }\end{array}$ \\
\hline
\end{tabular}

\section{References}

1. United Nations Environment Programme. Towards a Green Economy: Pathways to Sustainable Development and Poverty Eradication. Available online: https://sustainabledevelopment.un.org/index.php?page=view\& type $=400 \& n r=126 \&$ menu $=35$ (accessed on 25 July 2018).

2. Wu, X.; Zhang, L.; Luo, M. Discerning sustainability approaches in shipping. Environ. Dev. Sustain. 2019, 1-16. Available online: https://link_springer.xilesou.top/article/10.1007/s10668-019-00419-z (accessed on 11 November 2019). [CrossRef]

3. World Commission on Environment and Development. Report of the World Commission on Environment and Development: Our Common Future; United Nations: Geneva, Switzerland, 1987.

4. International Union for Conservation of Nature. Tenth General Assembly. Available online: https: //portals.iucn.org/library/efiles/documents/ns-sp-027.pdf (accessed on 28 July 2018).

5. White, L., Jr. The historical roots of our ecologic crisis. Science 1967, 155, 1203-1207. [CrossRef] [PubMed]

6. Sessions, G. The deep ecology movement: A review. Environ. Rev. 1987, 11, 105-125. [CrossRef]

7. Washington, H.; Taylor, B.; Kopnina, H.; Cryer, P.; Piccolo, J.J. Why ecocentrism is the key pathway to sustainability. Ecol. Citiz. 2017, 1,7.

8. The Economics of Ecosystems and Biodiversity. The Economics of Ecosystems and Biodiversity in Local and Regional Policy. Available online: http://www.teebweb.org/our-publications/teeb-study-reports/local-andregional-policy-makers/ (accessed on 25 July 2018).

9. Piccolo, J.; Durtsche, R.; Watz, J. Future rivers, dams and ecocentrism. Ecol. Citiz. 2019, 2, 173-177. 
10. Lamb, K.L. The problem of defining nature first: A philosophical critique of environmental ethics. Soc. Sci. J. 1996, 33, 475-486. [CrossRef]

11. United Nations Conference on Environment and Development. Transforming Our World: The 2030 Agenda for Sustainable Development. Available online: https://sustainabledevelopment.un.org/post2015/ transformingourworld/publication (accessed on 25 July 2018).

12. United Nations Framework Convention Climate Change. The Paris Agreement. Available online: https: //unfccc.int/process-and-meetings/the-paris-agreement/the-paris-agreement (accessed on 14 August 2019).

13. Benamara, H.; Hoffmann, J.; Youssef, F. Maritime transport: The sustainability imperative. In Sustainable Shipping: A Cross-Disciplinary View; Psaraftis, H.N., Ed.; Springer International Publishing: Cham, Switzerland, 2019; pp. 1-31.

14. International Maritime Organization. Strategic Plan for the Organization for the Six-Year Period 2018-2023. Available online: http://www.imo.org/en/About/strategy/Documents/A\%2030-RES.1110.pdf (accessed on 10 December 2018).

15. International Maritime Organization. The Initial IMO Strategy on Reduction of GHG Emissions from Ships. Available online: http://www.imo.org/en/OurWork/Documents/Resolution\%20MEPC.304\%2872\%29\%20on\% 20Initial\%20IMO \%20Strategy\%20on\%20reduction\%20of\%20GHG\%20emissions\%20from\%20ships.pdf (accessed on 12 January 2019).

16. International Maritime Organization. Sulphur 2020-Cutting Sulphur Oxide Emissions. Available online: http://www.imo.org/en/MediaCentre/HotTopics/Pages/Sulphur-2020.aspx (accessed on 14 August 2019).

17. Organization for Economic Co-operation and Development. ITF Transport Outlook. Available online: https://www.oecd-ilibrary.org/transport/itf-transport-outlook-2019_transp_outlook-en-2019-en (accessed on 14 August 2019).

18. Sciberras, L.; Silva, J.R. The UN's 2030 agenda for sustainable development and the maritime transport domain: The role and challenges of IMO and its stakeholders through a grounded theory perspective. WMU J. Marit. Aff. 2018, 17, 435-459. [CrossRef]

19. Tran, T.M.T.; Yuen, K.F.; Li, K.X.; Balci, G.; Ma, F. A theory-Driven identification and ranking of the critical success factors of sustainable shipping management. J. Clean. Prod. 2020, 243, 118401. [CrossRef]

20. Branch, A.E. Elements of Shipping, 8th ed.; Routledge: London, UK; New York, NY, USA, 2007.

21. United States Department of Transportation. The Maritime Administration and the U.S. Marine Transportation System: A Vision for the 21st Century. Available online: http://www.marad.dot.gov/ wp-content/uploads/pdf/Vision_of_the_21st_Century_10-29.pdf (accessed on 26 July 2018).

22. Rodriguez, L.; Youssef, F. Rethinking Maritime Cabotage for Improved Connectivity; United Nations Conference on Trade and Development: New York, NY, USA; Geneva, Switzerland, 2017; pp. 10-11.

23. Youssef, F.; Benamara, H.; Weller, M. UNCTAD Framework for Sustainable Freight Transport; United Nations Conference on Trade and Development: Geneva, Switzerland, 2017.

24. Wu, X.; Zhang, L.; Luo, M. Current strategic planning for sustainability in international shipping. Environ. Dev. Sustain. 2018, 1-19. Available online: https://link.springer.com/article/10.1007/s10668-018-00303-2 (accessed on 11 November 2019). [CrossRef]

25. Grünig, R.; Kühn, R. Process-Based Strategic Planning, 6th ed.; Springer: Berlin/Heidelberg, Germany; Dordrecht, The Netherlands; London, UK; New York, NY, USA, 2010.

26. Walmsley, S. Shipping and Sustainability. Available online: http://www.wwf.at/de/view/files/download/ showDownload/?tool=12\&feld=download\&sprach_connect=2395 (accessed on 26 July 2018).

27. Ioppolo, G.; Cucurachi, S.; Salomone, R.; Saija, G.; Shi, L. Sustainable local development and environmental governance: A strategic planning experience. Sustainability 2016, 8, 180. [CrossRef]

28. Lam, J.S.L.; Lim, J.M. Incorporating corporate social responsibility in strategic planning: Case of ship-operating companies. Int. J. Shipp. Transp. Logist. 2016, 8, 273-293. [CrossRef]

29. Bryson, J.M. Strategic Planning for Public and Nonprofit Organizations: A Guide to Strengthening and Sustaining Organizational Achievement; John Wiley \& Sons: San Francisco, CA, USA, 2011.

30. Frankel, E.G. Strategic planning applied to shipping and ports. Marit. Policy Manag. 1989, 16, $123-132$. [CrossRef]

31. Mukherjee, P.K.; Brownrigg, M. Farthing on International Shipping; Springer: Berlin/Heidelberg, Germany; New York, NY, USA; Dordrecht, The Netherlands; London, UK, 2013.

32. Branch, A.E. Branch's Elements of Shipping, 9th ed.; Routledge: Abingdon, UK, 2014. 
33. Ng, M.M.; Lun, Y.V.; Lai, K.-H.; Cheng, T. Research on shipping studies. Int. J. Shipp. Transp. Logist. 2013, 5, 1-12. [CrossRef]

34. Kuhlman, T.; Farrington, J. What is sustainability? Sustainability 2010, 2, 3436-3448. [CrossRef]

35. McShane, K. Anthropocentrism vs. Nonanthropocentrism: Why should we care? Environ. Values 2007, 16, 169-185. [CrossRef]

36. Zhang, L.; Xu, H.; Sheng, H.; Chen, W.; Fang, Q. Concept and evaluation of ecosystem intrinsic value. J. Agric. Sci. Technol. B 2015, 5, 401-409.

37. Sheng, H.; Xu, H.; Zhang, L.; Chen, W. Ecosystem intrinsic value and its application in decision-Making for sustainable development. J. Nat. Conserv. 2019, 49, 27-36. [CrossRef]

38. Keeney, R.L. Creativity in decision making with value-Focused thinking. Sloan Manag. Rev. 1994, 35, $33-41$.

39. Batavia, C.; Nelson, M.P. For goodness sake! What is intrinsic value and why should we care? Biol. Conserv. 2017, 209, 366-376. [CrossRef]

40. Yuen, K.F.; Li, K.X.; Xu, G.; Wang, X.; Wong, Y.D. A taxonomy of resources for sustainable shipping management: Their interrelationships and effects on business performance. Transp. Res. Part E: Logist. Transp. Rev. 2019, 128, 316-332. [CrossRef]

41. Yuen, K.F.; Wang, X.; Wong, Y.D.; Ma, F. A contingency view of the effects of sustainable shipping exploitation and exploration on business performance. Transp. Policy 2019, 77, 90-103. [CrossRef]

42. Zhang, L.; Chen, W.; Fang, Q.; Wang, P.; Hong, H.; Bristow, F. Resources-Oriented principle and sustainability: Theory and application in china. Environ. Inf. Arch. 2006, 4, 459-464.

43. Transport and Infrastructure Council of Australia. National Guidelines for Transport System Management in Australia. Available online: https://ngtsmguidelines.com/ (accessed on 10 March 2019).

44. Kaszuba, M. Implementing the precautionary principle. Sci. Total Environ. 2002, 288, 155-165.

45. International Organization for Standardization. Environmental Management-Life Cycle Assessment-Principles and Framework. Available online: https://www.iso.org/standard/37456.html (accessed on 10 March 2019).

46. International Organization for Standardization. ISO 14001: Environmental Management Systems-Requirements with Guidance for Use. Available online: https:/www.iso.org/standard/60857.html (accessed on 10 March 2019).

47. Zhang, L.; Mu, R.; Zhang, R. Multiple dimensional decision-Making approach: A new way of strategic decision-making. J. Strategy Decis. Mak. 2014, 1, 71-83. (In Chinese)

48. Mu, R. Principal Coastal Functional Zoning Based on Multi-Dimensional Decision Making (MDDM). Ph.D. Thesis, Xiamen University, Xiamen, China, 2013. (In Chinese).

49. Wu, K.; Zhang, L. Application of environmental risk assessment for strategic decision-Making in coastal areas: Case studies in china. J. Environ. Plan. Manag. 2016, 59, 826-842. [CrossRef]

50. Lawer, E.T. Examining stakeholder participation and conflicts associated with large scale infrastructure projects: The case of tema port expansion project, ghana. Marit. Policy Manag. 2019, 1-22. [CrossRef]

51. Wu, K.; Zhang, L.; Fang, Q. An approach and methodology of environmental risk assessment for strategic decision-making. J. Environ. Assess. Policy Manag. 2014, 16. [CrossRef]

52. Mohamed, S.T. The impact of ISO 14000 on developing world businesses. Renew. Energy 2001, 23, 579-584. [CrossRef]

53. International Organization for Standardization. ISO 14001 Key Benefits. Available online: http://www.iso. org/iso/iso_14001_-_key_benefits.pdf (accessed on 10 March 2019).

54. Magerholm Fet, A. ISO 14000 as a strategic tool for shipping and shipbuilding. J. Ship Prod. 1998, 14, $155-163$.

55. Beizadea, E.H. Applications of life cycle assessment (LCA) in shipping industry. In Proceedings of the 14th International Multidisciplinary Scientific Geo-Conference and Expo, Sofia, Bulgaria, 17-26 June 2014; Zhang, Z., Ed.; pp. 1-8.

56. Panaitescu, F.; Panaitescu, M. An approach to the implementation of ISO 14000 at a shipping company. In IOP Conference Series: Materials Science and Engineering; IOP Publishing: Bandung, Indonesia, 2015; Volume 95, pp. 1-6.

57. Nahlik, M.J.; Kaehr, A.T.; Chester, M.V.; Horvath, A.; Taptich, M.N. Goods movement life cycle assessment for greenhouse gas reduction goals. J. Ind. Ecol. 2016, 20, 317-328. [CrossRef]

58. Zhuang, P. Maritime Logistics and Port City_Region Development; Science Press: Beijing, China, 2014. (In Chinese) 
59. Litman, T. Economic Evaluation for Transportation Decision-Making. Available online: http://www.vtpi.org/ worth.pdf (accessed on 19 January 2019).

60. Standing Committee of the National People's Congress of the People's Republic of China. Law of the People's Republic of China on Environmental Impact Assessment. Available online: http://fgs.mee.gov.cn/fl/ 201901/t20190114_689451.shtml (accessed on 10 March 2019). (In Chinese)

61. International Institute for Environment and Development. A Directory of Impact Assessment Guidelines; Russell Press: Nottingham, UK, 1998.

62. MacKinnon, A.J.; Duinker, P.N.; Walker, T.R. The Application of Science in Environmental Impact Assessment; Routledge: London, UK; New York, NY, USA, 2018.

63. Chen, B. Research on the Practice of Strategic Environmental Assessment. Master's Thesis, Xiamen University, Xiamen, China, 2002. (In Chinese).

64. Kjorven, O.; Lindhjem, H. Strategic Environmental Assessment in World Bank Operations. Available online: http://siteresources.worldbank.org/INTSTRENVASS/Publications/20687529/ESP4StrategicEA2002. pdf (accessed on 10 March 2019).

65. Huang, W. Theoretical System and Approaches of Retrospective Assessment in Strategic Environmental Assessment. Master's Thesis, Xiamen University, Xiamen, China, 2008. (In Chinese).

66. Bina, O. Strategic Environmental Assessment of Transport Corridors: Lessons Learned Comparing the Methods of Five Member States. Available online: http://ec.europa.eu/environment/archives/eia/sea-studiesand-reports/pdf/sea_transport2.pdf (accessed on 15 December 2018).

67. International Organization for Standardization. ISO 31000: Risk Management-Principles and Guidelines. Available online: https://www.iso.org/obp/ui/\#iso:std:iso:31000:ed-1:v1:en (accessed on 10 March 2019).

68. International Organization for Standardization; International Electrotechnical Commission. ISO/IEC 31010: Risk Management-Risk Assessment Techniques. Available online: https://www.iso.org/standard/51073.html (accessed on 10 March 2019).

69. Yu, W.; Zhang, L.; Ricci, P.F.; Chen, B.; Huang, H. Coastal ecological risk assessment in regional scale: Application of the relative risk model to Xiamen Bay, China. Ocean Coast. Manag. 2015, 108, 131-139. [CrossRef]

70. Yu, W. Ecological Risk Assessment of Strategic Decision Making in Coastal Area. Ph.D. Thesis, Xiamen University, Xiamen, China, 2012. (In Chinese).

71. Costanza, R.; d'Arge, R.; De Groot, R.; Farber, S.; Grasso, M.; Hannon, B.; Limburg, K.; Naeem, S.; O'neill, R.V.; Paruelo, J. The value of the world's ecosystem services and natural capital. Nature 1997, 387, 253-260. [CrossRef]

72. Burkhard, B.; Petrosillo, I.; Costanza, R. Ecosystem services-bridging ecology, economy and social sciences. Ecol. Complex. 2010, 7, 257-259. [CrossRef]

73. Wang, X.; Chen, W.Q.; Zhang, L.P.; Jin, D.; Lu, C.Y. Estimating the ecosystem service losses from proposed land reclamation projects: A case study in Xiamen. Ecol. Econ. 2010, 69, 2549-2556. [CrossRef]

74. Wang, X. Coastal ecosystem service valuation: Theoretical Implication, Integrated Multidisciplinary Approaches and Case Studies. Ph.D. Thesis, Xiamen University, Xiamen, China, 2011. (In Chinese).

75. Peng, B.; Hong, H. Evaluation of Coastal Ecosystem Services Theory and Application; Ocean Press: Beijing, China, 2006. (In Chinese)

76. Yuen, K.F.; Wang, X.; Wong, Y.D.; Zhou, Q. The effect of sustainable shipping practices on shippers' loyalty: The mediating role of perceived value, trust and transaction cost. Transp. Res. Part E Logist. Transp. Rev. 2018, 116, 123-135. [CrossRef]

77. Shipfinder. Ship Tacking. Available online: http://www.shipfinder.com/ (accessed on 17 January 2019).

78. Agenzia Regionale per la Prevenzione e Protezione Ambientale del Veneto. Risorsa idrica. Available online: http://www.arpa.veneto.it/arpavinforma/bollettini/acqua-1/risorsa-idrica (accessed on 10 December 2018). (In Italian).

79. Italian National Institute of Statistics. Regional Datasets of Veneto. Available online: https://www.istat.it/en/ veneto (accessed on 10 December 2018).

80. Agenzia Regionale per la Prevenzione e Protezione Ambientale del Veneto. Risultati monitoraggio ecologico 2013 2015-laguna di Venezia. Available online: http://www.arpa.veneto.it/temi-ambientali/acqua/file-eallegati/documenti/acque-di-transizione/Risultati\%20monitoraggio\%20ecologico\%202013\%202015\%20\%20Laguna\%20di\%20Venezia.pdf/view (accessed on 10 December 2018). (In Italian). 
81. Transport Planning and Research Institute of Ministry of Transport. Environmental Impact Assessment Report on Master Plan (Revised) for Port of Xiamen; Transport Planning and Research Institute of Ministry of Transport: Xiamen, China, 2014. unpublished. (In Chinese)

82. Wu, X.; Zhang, L.; Dong, Y.-W. Towards sustainability in Xiamen Harbor, China. Reg. Stud. Mar. Sci. 2019, 27. [CrossRef]

83. Weber, R.H.; Weber, R. Internet of Things; Springer: Berlin/Heidelberg, Germany; Dordrecht, The Netherlands; London, UK; New York, NY, USA, 2010. article distributed under the terms and conditions of the Creative Commons Attribution (CC BY) license (http://creativecommons.org/licenses/by/4.0/). 